\title{
Smart Eco-City Strategies and Solutions for Sustainability: The Cases of Royal Seaport, Stockholm, and Western Harbor, Malmö, Sweden
}

\author{
Simon Elias Bibri ${ }^{1,2, *}$ and John Krogstie ${ }^{1}$ \\ 1 Department of Computer Science, The Norwegian University of Science and Technology, \\ Sem Saelands veie 9, NO-7491 Trondheim, Norway; john.krogstie@ntnu.no \\ 2 Department of Architecture and Planning, The Norwegian University of Science and Technology, \\ Alfred Getz vei 3, Sentralbygg 1, 5th floor, NO-7491 Trondheim, Norway \\ * Correspondence: simoe@ntnu.no
}

Received: 13 December 2019; Accepted: 20 February 2020; Published: 3 March 2020

\begin{abstract}
Sustainable urbanism is seen today as one of the keys towards unlocking the quest for a sustainable society. As a central paradigm of sustainable urbanism, the eco-city is promoted by global and local policies as one of the preferred responses to the challenges of sustainable development. It is argued that eco-city strategies are expected to deliver positive outcomes in terms of providing healthy and livable human environments in conjunction with minimal demand on resources and thus minimal environmental impacts. As such, it is pertinent to examine how the eco-city model and especially its three sustainability dimensions is practiced and justified in urban planning and development at the local level. This is motivated by the increased interest in developing sustainable urban districts. In this light, this study seeks to answer the following two questions: What are the key strategies of the eco-city district model, and in what ways do they mutually complement one another in terms of producing the expected tripartite value of sustainability? To what extent does the eco-city district model support and contribute to the environmental, economic, and social goals of sustainability? To illuminate the phenomenon of the eco-city district accordingly, a descriptive case study is adopted as a qualitative research methodology, where the empirical basis is mainly formed by urban planning and development documents in two eco-city districts-Royal Seaport, Stockholm, and Western Harbor, Malmö, Sweden - in combination with qualitative interview data, secondary data, and scientific literature. This study shows that the eco-city district models of SRS and Western Harbor involve mainly design and technology, supported with behavioral change, as key strategies and solutions for achieving urban sustainability. Design encompasses greening, passive solar houses, sustainable transportation, mixed land use, and diversity. And technology comprises green technologies, energy efficiency technologies, and waste management systems. Design contributes to the three goals of sustainability, and technology contributes mostly to the environmental and economic goals of sustainability. Behavioral change is associated with sustainable travel, waste separation, and energy consumption. Moreover, at the core of the eco-city district model is the clear synergy between the underlying strategies in terms of their cooperation to produce combined effects greater than the sum of their separate effects with respect to the benefits of sustainability. Further, this study demonstrates that while the environmental, economic, and social goals of sustainability are represented in eco-city district strategies on a discursive level, institutionalized planning practices show that the environmental goals remain at the core of planning, while the economic and social goals still play second fiddle. Nevertheless, new measures have recently been implemented in Western Harbor that are expected to strengthen their influence over urban development practices, whereas the Royal Seaport program mainly focuses on the environmental and some economic aspects, which is a shortcoming that should be recognized and dealt with.
\end{abstract}


Keywords: eco-city; sustainable city; sustainable urbanism; planning practice; development strategy; sustainability goals; technology; design; smart solution; Sweden

\section{Introduction}

Since its widespread diffusion in the early 1990s, sustainable development has significantly influenced urban planning and development as manifested in the emergence and prevalence of sustainable urban forms across the globe, especially eco-cities. A number of recent international reports and policy papers argue that the eco-city model has positive effects on resource efficiency, climate change, citizen health, and economic growth, and there are numerous actors involved in the academic and practical aspects of the endeavor of ecological urbanism, undertaking research and developing and implementing policies to tackle the underlying challenges.

In the early 1990s, the discourse on sustainable development led to the emergence of the eco-city model, which has become one of the preferred responses to the challenges of sustainable development. Richard Register defined an eco-city in 1987 as 'an urban environmental system in which input (of resources) and output (of waste) are minimized' [1]. As the concept has become more established, the meanings associated with it and the diversity of initiatives and projects adopting the label have spread worldwide. However, as an umbrella concept, the eco-city encompasses a wide range of urban-ecological proposals that aim to achieve sustainability. These approaches emphasize renewable energy (e.g., solar, wind, geothermal, etc.), passive solar design, green structure, ecological and cultural diversity, and environmentally sound policies [2,3]. They propose a wide range of land use, environmental, economic, social, and institutional policies that are directed towards managing urban spaces to achieve sustainability. Remarkably, management is the core of many approaches to the eco-city. As such, this encompasses how the urban landscape is organized and steered rather than the physical shape of the city and thus its spatial arrangements. Hence, the city is managed to achieve sustainability through different policies related to its dimensions [4-7]. For example, the well-known Agenda 21 of United Nations Conference on Environment and Development proposes integrated management at the urban level to ensure that environmental, economic, and social factors are considered together in a framework for the sustainable city [6]. An eco-city secures ecologically sound, socially beneficial, and economically viable development that is supported by planning, design, and transportation $[8,9]$.

However, in the current climate of unprecedented urbanization and increased uncertainty, it may be more challenging for cities in developed countries to configure themselves more sustainably/ecologically. The predicted $70 \%$ rate of urbanization by 2050 [10] reveals that urban sustainability/ecology is a key factor in global resilience and viability to forthcoming changes. This implies that the city governments will face significant challenges pertaining to environmental, economic, and social sustainability due to the issues engendered by urban growth. These include increased energy consumption, pollution, toxic waste disposal, resource depletion, inefficient management of urban infrastructures and facilities, inadequate planning processes and decision-making systems, poor housing and working conditions, saturated transport networks, endemic congestion, and social inequality and vulnerability [11,12]. In a nutshell, urban growth raises a variety of problems that tend to jeopardize the sustainability of cities, as it puts an enormous strain on urban systems and processes as well as on ecosystem services. Therefore, much emphasis has been placed on framing sustainability in cities around the world [13]. One aspect of such framing is the increasing interest in planning and developing environmentally sound and sustainable urban districts as a center for innovations and practical implementation, and as a way of incorporating sustainability in the built environment and hence redesigning and restructuring urban places.

A large body of work has investigated the presumed outcome of the eco-city achieved through planning practices and design strategies. More specifically, scholars have discussed to what 
extent it produces the expected environmental, economic, and social benefits of sustainability (e.g., $[2,8,14-17]$ - - with more of a focus on the natural environment and ecosystems than economic and social aspects [18]. This line of research thus directs attention to either the ecological dimension of sustainability or the tripartite composition of sustainable development. Moreover, a recent wave of research has started to focus on amalgamating ecological cities and sustainable cities with smart cities on the basis of advanced Information and Communication Technology (ICT), especially big data technology and its novel applications, to improve the contribution of sustainable urban forms to the goals of sustainable development (e.g., $[2,3,11,14,19-26])$. These research areas open the way for cross-domain analyses in terms of addressing and integrating the environmental, economic, and social facets of the eco-city. This study follows this path by examining how the eco-city district, and especially its three sustainability dimensions, is practiced and justified in urban planning and development. The two research questions driving this research are: what are the key strategies and solutions of the eco-city district model, and in what ways do they mutually complement one another in terms of producing the expected tripartite value of sustainability? To what extent does the eco-city district model support and contribute to the environmental, economic, and social goals of sustainability? To illuminate the phenomenon of the eco-city district accordingly, a descriptive case study is adopted as a qualitative research methodology, where the empirical basis is mainly formed by urban planning and development documents in two Swedish eco-city districts-Royal Seaport, Stockholm, and Western Harbor, Malmö-in combination with qualitative interview data, secondary data, and scientific literature.

This article unfolds as follows. Section 2 describes and discusses the eco-city in terms of definitions, models, ideals, and research gaps. Section 3 outlines, justifies, and elaborates the research methodology. Section 4 presents the results. Section 5 discusses the results. Finally, the article concludes, in Section 6, by summarizing the main findings, providing some reflections, and suggesting some avenues for future research.

\section{Eco-City as an Approach to Sustainable Cities}

\subsection{Definitions}

There are multiple views on what a sustainable city should be or look like and thus various ways of conceptualizing it. Generally, a sustainable city can be understood as a set of approaches into operationalizing sustainable development in or practically applying the knowledge about sustainability and related technologies to the planning and design of existing and new cities or districts. It represents an instance of sustainable urban development, a strategic approach to achieving the long-term goals of urban sustainability. Accordingly, it needs a balance between the environmental, economic, and social goals of sustainability as an integrated process. Such a balance can lead more opportunity to make the city greener, fairer, and more profitable for different stakeholders (Figure 1).

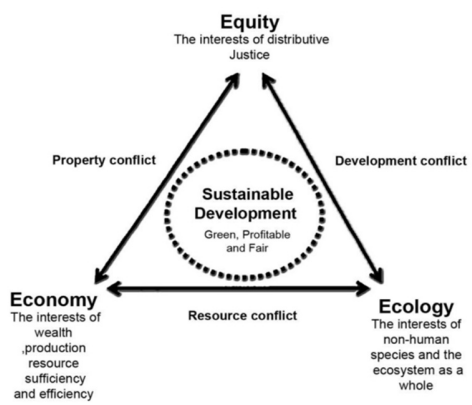

Figure 1. Triangular conflict among key contributors to achieve sustainability. Source: [27].

Sustainable cities have been the leading global paradigm of urbanism (e.g., $[6,11,13,28]$ ) for more than three decades. There are different approaches to sustainable cities, which are identified as models 
of sustainable urban forms, including eco-cities, compact cities, green cities, new urbanism, landscape urbanism, and urban containment. Of these, eco-cities are often advocated as a more environmentally sound and sustainable approach.

The idea of the eco-city is widely varied in conceptualization and operationalization. To put it differently, there are multiple definitions of the eco-city, depending on the context-urban initiatives and projects in terms of the planning and development practices pursued to achieve it. Generally, an eco-city is a human settlement which emphasizes the self-sustaining resilient structure and function of the natural environment and ecosystems. It seeks to provide a healthy and livable human environment without consuming more renewable resources than it replaces. Roseland [9] argues that there is no single accepted definition of the eco-city, rather a collection of ideas about concepts.

\subsection{Eco-City Models}

It is not an easy task to develop a clear, comprehensive vision of what an eco-city actually looks like. Indeed, there are different models of the eco-city focusing on planning and developing sustainable cities and communities based mainly on two key distinctive design principles and strategies, namely passive solar design and greening $[6,14]$. While these models share some features, in many cases, they focus on different aspects and comply with different criteria, including taking a holistic approach, interconnections of subsystems, adaptability, and planning and design procedures, with a substantial focus on the ecological aspects of sustainability. Examples of models that emphasize passive solar design include the ecovillage, solar village [29], Solar City [30], and cohousing [31]. Examples of models that combine passive solar design and greening include Eco-City $([9,32])$, Ecological City [33], the Environmental City, Green City, Sustainable City ([34-36]), Sustainable Neighborhood [37], Sustainable Urban Living [38], Living Machines [39], and Garden City [40].

Other models, which are based on a particular set of green or smart technology solutions for achieving the goals of environmental sustainability, include SymbioCity [41], Carbon Neutral City, Zero Energy City, Zero Carbon City, eco-Municipality, eco-Industrial Park [30], Low Carbon City ([31,41]), Net Zero Carbon Community [42], Eco2 City [43], Smart Eco-City ([22,25]), and Ubiquitous Eco-City [26].

In light of the above, what exactly constitutes the eco-city as an overarching approach to sustainable urbanism seems to be even more unclear and thus difficult to pin down. Today an ever-increasing range of existing districts, cities, as well as new and planned urban initiatives and projects are labelled eco-cities [17]. Eco-districts focus on community collaboration, integrated communication, and management to help cities to be more successful by working together. Nevertheless, the way ecological urban initiatives and projects conceive of the eco-city status reflects more divergences than convergences $[3,14]$. In other words, the guiding planning documents in this regard tend to be largely developed as independent islands of locally ecological sustainability. Accordingly, it is more appropriate to think of the eco-city as an ambition that can be achieved through multiple ways.

\subsection{Eco-City Ideals}

The implicit image of an eco-city has proven to be a highly influential translation of what a sustainable city should be, carried by the significance of the design principles and strategies underlying this model of sustainable urban form $[11,14,19]$. Ideally, an eco-city secures ecologically sound, socially beneficial, and economically viable development that is supported by sustainable planning, design, and transportation through a set of policies covering the different aspects of urban sustainability. A well-designed eco-city should be able to achieve all of the benefits of sustainability. Accordingly, the eco-city becomes an all-encompassing concept for urban policy making processes and planning practices. Irrespective of the way the idea of the eco-city has been, and can be, conceptualized and operationalized, there are still some criteria that have been proposed to identify what an ideal 'eco-city' is or looks like, comprising the environmental, social, and economic goals of sustainable development. Irrespective of the way the idea of the eco-city has been, and can be, conceptualized and operationalized, 
there are still some criteria that have been proposed to identify what an ideal 'eco-city' is as aiming for the environmental, social, and economic goals of sustainability (Table 1):

Table 1. Criteria of an ideal eco-city. Sources: $([8,9])$.

- Operates on a self-contained local economy that obtains resources locally

- Maximizes energy and water efficiency, thereby promoting conservation of resources

- Manages an ecologically beneficial waste management system that promotes recycling and reuse to create a zero-waste system

- $\quad$ Promotes the use and production of renewable energy, thereby being entirely carbon neutral

- Has a well-designed urban city layout that promotes walkability, biking, and the use of public transportation systems

- $\quad$ Ensures decent and affordable housing for all socio-economic and ethnic groups and improves jobs opportunities for disadvantaged groups

- $\quad$ Supports urban and local farming

- Supports future progress and expansion over time.

As added by Graedel (1999) [44], the eco-city is scalable and evolvable in design in response to urban growth and need changes. However, scholars have often critically discussed to what extent the eco-city produces the expected environmental, economic, and social benefits of sustainability. Ideally, for sustainability to be achieved, its environmental, economic, and social dimensions need to be in balance. Whether this is actually the case in the eco-city initiatives or projects varies from one to another (see [17] for further discussion).

\subsection{Research Gaps and Issues}

The issue of sustainable cities has been problematic, whether in theory or practice [12,14], and so is knowing to what extent we are making progress towards urban sustainability in the face of urbanization [11,13]. It is not an easy task to judge whether or not a certain model of sustainable cities is sustainable [45]. However, the ultimate goal of the endeavor is to develop a more theoretically and practically robust model of sustainable cities [2,3]. This has indeed been one of the most significant intellectual and practical challenges for more than three decades (e.g., [6,11-14,19,45]). As concluded by Jabareen (2006) [6], neither real-world cities nor scholars have yet developed convincing models of sustainable cities. In a nutshell, sustainable cities are associated with a number of problems, issues, and challenges, and hence much more needs to be done considering the very fragmented, conflicting picture that arises of change on the ground in the face of the expanding urbanization. Bibri and Krogstie [2] provide a detailed critical review of eco-cities as an approach to sustainable cities in terms of their deficiencies, limitations, difficulties, and uncertainties, as well as the opportunities being offered by advanced ICT to address them.

The eco-city has been criticized as an idea that is loosely defined from a set of ostentatiously attractive projects as expensive schemes with aesthetic and commercial ends intended to satisfy a local or regional ambition to invest in ecological sustainability without posing a more theoretically focused and globally applicable approach. In addition, Cugurullo (2016) [46] questions the sustainability of the so-called eco-city by investigating the extent to which it is developed in a controlled and systematic manner as its developers claim. More specifically, the author counterclaims mainstream understandings of ecological urbanism, arguing that what are promoted as cohesive settlements shaped by a homogeneous vision of the sustainable city are actually fragmented cities made of disconnected and often incongruous pieces of urban fabric. In reference to eco-cites, Holmstedt, Brandt and Robert (2017) [47] point out that implementing sustainable solutions is more difficult because no unified practical definition is still accepted even if the subject of sustainability has been hotly debated more than three decades, and most projects act dishonesty in order to gain an advantage by not defining what is meant by sustainability and not meeting all requirements. In addition, in urban planning and 
policy making, the concept of the eco-city 'has tended to focus mainly on infrastructures for urban metabolism - sewage, water, energy, and waste management within the city' [23] (p. 3), thereby falling short in considering smart solutions in relation to urban processes and practices (e.g., $[11,12,14,24,48])$.

\section{Research Methodology}

\subsection{Case Study Inquiry}

Case study research has long been of prominence in many disciplines. As a research methodology, case study research is well established in the social sciences and other scientific and technological fields. Creswell et al. (2007) [49] describe the case study methodology as a type of design in qualitative research, an object of study, and a product of the inquiry. The authors conclude with a definition that collates the hallmarks of key approaches and that represents the core features of a case study: 'a qualitative approach in which the investigator explores a bounded system (a case) or multiple bounded systems (cases) over time through detailed, in-depth data collection involving multiple sources of information ... and reports a case description and case-based themes' [49] (p. 245). The case study approach is usual when multiple sources of evidence are used [50,51], e.g., documents and reports, observations, interviews, and so on. The use of multiple methods to collect and analyze data is found to be mutually informative in case study research, together providing a more synergistic and comprehensive view of the issue being studied ([51-55]).

\subsection{Descriptive Case Study Characteristics}

Case study research can be used to study a range of topics [51,54,56,57]. With that in mind, this case study uses a descriptive design - an approach which is focused and detailed, and in which questions and propositions about the phenomenon of the eco-city are carefully scrutinized and articulated at the outset. The articulation of what is already known about this phenomenon is called a descriptive theory, which pertains to sustainable urban forms in this context. Therefore, the main goal of this descriptive case study is to assess the selected cases in detail and in depth based on that articulation of a descriptive theory. This research design intends to describe the phenomenon of the eco-city in its real-world context $[21,51]$. Worth noting is that there is not enough evidence to support this phenomenon or explain how or why it works.

Descriptive research here involves the description, analysis, and interpretation of the present nature, composition, and processes of two Swedish cities, where the focus is on the prevailing conditions, or how these cities behave or function in the present in terms of what has been realized and the implementation of plans based on the corresponding practices and strategies. This entails the ongoing and future activities to be undertaken in accordance with the time horizon set in the planning and development documents. Moreover, as an urban event based on two instances, the eco-city involves a set of indicators of an integrated city system in operation that requires an analysis to allow obtaining a broad and detailed knowledge about such system. To achieve this objective, this descriptive case study consists of the following steps:

- Using a narrative framework that focuses on the eco-city as a real-world problem and provides essential facts about it, including relevant background information.

- Introducing the reader to key concepts, strategies, and policies relevant to the problem under investigation.

- Explaining the actual solutions in terms of plans, the processes of implementing them, and the outcomes.

- Offering analysis and evaluation of the chosen solutions and related issues, including strengths, weaknesses, tradeoffs, and lessons learned.

Considering the above, one of the essential requisites for employing case studies stems from one's motivation to illuminate a complex phenomenon $[51,53,54]$. 


\subsection{Selection Criteria, Unit of Analysis, and Data Collection and Analytical Methods}

The rationale for selecting Swedish eco-city districts as cases for investigation is that Sweden is among the Scandinavian countries that have exemplary practical initiatives in sustainable cities, notably eco-cities. According to several rankings, Sweden, Norway, Finland, Germany, the Netherlands, and Japan have the highest level of sustainable development practices [58]. Several empirical studies identify, from the mid-1980s onward, increasing ecological disruption in most of the ecologically advanced nations, such as Sweden, Denmark, Germany, the Netherlands, and Japan [59].

In the context of this article, the two Swedish cities selected have been receptive to the eco-city ideal as well as engaged in ecological planning for almost two decades. They have chosen the eco-city strategy as the most effective planning system that can go hand in hand with sustainable development in light of the relevance and usefulness of the findings produced by many studies in the field of sustainable urbanism. As such, they are seen as successful examples of ecological urbanism, as well as critical cases in sustainable urban development. This is due to their long planning traditions and the existence of relatively solid economic resources at the local level, the national focus on sustainability in Sweden, and the wide authorization given to local authorities [60,61]. Moreover, they express environmental and sustainability ambitions in their master and comprehensive plans, support progress and expansion over time, and experience developmental pressure on their landscapes due to urbanization. Additionally, it was important to ensure that there was sufficient information available in the public realm to conduct an analysis on these two cases. On the basis of all these criteria, Royal Seaport in Stockholm and Western Harbor in Malmö have been selected as eco-city districts for investigation. They illustrate how ambitious districts handle the environmental and sustainability challenges, and how different values and interests are weighted and secured through urban planning and development.

The unit of analysis, the entity that frames what is being analyzed in this study, includes the strategies of the eco-city model and the extent to which they produce the environmental, economic, and social benefits of sustainability. This is essential to focalizing, framing, and managing data collection and analysis. To identify the perceived link between the eco-city dimensions and the environmental, economic, and social goals of sustainability, the common concepts related to the eco-city model (notably greening, passive solar design, energy, waste, and transportation) were searched for in the two cities' comprehensive plans. The broad concepts represented by these terms linked to the environmental, economic, and social sustainability goals were then mapped. This procedure enabled us to focus on strategies and goals directly linked to the eco-city city model.

In addition, the two districts' master plans, programs, policy documents, and project descriptions were identified and analyzed using a thematic analysis, which is a widely used analytical technique within qualitative research. Thematic analysis is particularly (albeit not exclusively) associated with the analysis of textual material. Generally, this approach emphasizes identifying, analyzing, interpreting, and reporting themes, i.e., important patterns of meaning within qualitative data that can be used to address the problem under investigation. Thematic analysis is generally flexible in terms of theoretical and research design given that it is not dependent on any particular theory or epistemology: multiple theories can be applied to this process across a variety of epistemologies.

Thematic analysis is an umbrella term for a variety of different approaches, which are divergent in regard to procedures. We adopted an inductive approach to thematic analysis, which involves allowing the data to determine the set of themes that is to be identified. That is to say, we developed our own framework based on what we find as themes (inductive) by discovering patterns, themes, and concepts in the data.

The main steps of the analytical process are as follows:

1. Review of city data (i.e., master plans, programs, policy documents, and project descriptions, etc.) and the scientific literature that is related to the eco-city model. The outcomes of this process are numerous themes that are associated with this model. It is important to obtain a comprehensive 
understanding of the content of the documents and scientific literature and to be familiarized with all aspects of the data. This step provides the foundation for the subsequent analysis.

2. Pattern recognition (searching for themes) entails the ability to see patterns in seemingly random information. The aim is to note major patterns within the result of the first step. This second step looks for similarities within the sample and codes the results by concepts and themes. Coding involves identifying passages of text that are linked by a common theme, indexing the text into categories and therefore establishing a framework of thematic ideas about it. In this step, the preliminary codes identified are the features of the data that appear interesting and meaningful, and the relevant data extracts are sorted according to overarching themes. It is important to allude to the relationship between codes and themes.

3. Reviewing and naming themes are about combining, separating, refining, or discarding initial themes, as well as naming them, in accordance with the three dimensions of sustainability as related to the eco-city model. Data within themes should cohere together meaningfully and be clear and identifiable in terms of the distinction between them. A thematic 'map' is generated from this step. Subsequently, theme names are provided with clear working definitions capturing the essence of each theme.

4. Producing the report involves transforming the analysis into an interpretable piece of writing by using vivid and compelling data extracts that relate to the themes, research question, and literature. The report must go beyond a mere description of the themes and portray an analysis supported with empirical evidence that addresses the research questions.

Furthermore, the results of the document analysis were triangulated with local thematic plans relevant to the three dimensions of sustainability, and to information from the two cities' websites, newspaper articles/internet discussions, observations, and interviewees.

Primary data were collected through face-to-face and telephone interviews with a total of 10 interviewees, including planners, architects, developers, and administrative servants. They were selected from the ongoing projects of SRS and Western Harbor, especially those working within the areas that involve contentious and challenging issues based on both the outcome of the previous empirical studies carried out in relevance to this study as well as the arguments advanced by the critics of the eco-city model. One of the key objectives of the interviews was to corroborate the progress made by the two municipalities as to the development and implementation of new measures to address the issues related to the economic and social dimensions of sustainability. As regards the environmental dimension of sustainability, the objective of the interviews was to document the practical advances claimed to be made in the field of sustainable urban development, as well as the extent to which the eco-city district strategies have been implemented according to the plan.

The interviews were mostly unstructured and guided by the three sustainability dimensions in terms of the past and current issues related to the above mentioned topics. They were meant to be used in ways that can be adapted to the interviewees' roles and interests. This means that the interviewees were asked different questions. Findings were reported as statements relating to the three dimensions of sustainability in terms of strategies and solutions, and included complementing, substantiating, and conflicting statements.

In addition, a set of face-to-face and telephone conversations was conducted with some researchers and scholars at Lund University, Malmö University, and Royal Institute of Technology. This was particularly important in providing insights into some ongoing projects and useful knowledge regarding environmental sustainability in the context of sustainable cities. As far as the face-to-face conversations are concerned, they took place with no schedule set in advance, whenever the circumstances allowed.

\subsection{On the Case Study Cities and Districts}

Centrally located in the growing Baltic region, Stockholm is the largest city in Sweden, the capital of Sweden, and the most populous urban area in Scandinavia. Approximately 1.6 million people live in the urban area, 2.4 million in the metropolitan area, and 965,232 in the municipality. Moreover, Stockholm 
is an important global city and one of the world's cleanest capitals and metropolises due to the absence of heavy industry and fossil fuel power plants. Indeed, it has a long history of environmental work and was the first city to be granted the European Union's Green Capital award by the European Commission in 2010 [62] because of its high environmental standards and ambitious goals for further environmental improvement. This involves climate change, public green areas, air quality, waste and water management, wastewater treatment, sustainable land use, environmental management, and sustainable transport. In particular, the city has a long-term commitment to sustainable development and environmental enhancement.

The City of Stockholm is at the forefront of ecological thinking. It has very strong environmental policies and is focused on improving the quality of life of its citizens [63]. It argues that climate-adapted solutions will minimize energy use, waste, and transport requirements [64,65]. Hammarby Sjöstad will serve as a starting point in the quest for sustainable solutions for energy usage, waste handling, and transportation [65]. Accordingly, drawing on the lessons learned and the experiences gained from Hammarby Sjöstad, SRS as a world-class environmental city district has set three ambitious environmental goals, namely [66]:

1. To reduce $\mathrm{CO}_{2}$ emissions from 4.5 tonnes in 2008 to a level below 1.5 tonnes per inhabitant by 2020 .

2. To be fossil fuel free and climate + by 2030 .

3. To be adapted to a changed climate, i.e., increasing precipitation.

In recent years, much of the environmental work within Stockholm has focused on developing new sustainable urban districts. One recent initiative, in addition to Hammarby Sjöstad, is the Stockholm Royal Seaport (SRS) district, with a vision to transform this district into a world class environmental city district. SRS is an area of 236 hectares that is being transformed from a brownfield zone into a site of 12,000 homes, 35,000 workplaces, $600,000 \mathrm{~m}^{2}$ of commercial spaces, and parks and green spaces, with approximately 35,000 people to live and/or work in the area.

SRS is designated as an environmental profile area with the mandate to become a model of sustainable urban development [66]. It is among the key climate-positive projects in the world that are considered as examples of successful environmental and economic urban developments, demonstrating that cities can reduce carbon emissions and grow in climate friendly ways. While the vision of SRS is to become a world-class environmental city, its goals are ecological, economic, and social sustainability. Its vision relates to the goal established by the City of Stockholm to be fossil fuel free by 2050 [67]. In this respect, the SRS environmental profile should consolidate Stockholm's position as a leading capital in climate work, support the marketing of Swedish environmental technology, and contribute to the development of new technology [65]. The program for SRS aims to lead the way for SRS to become an environmentally and sustainably sound urban district, managing all three pillars of sustainability.

Malmö is the largest city of the Swedish County of Skåne and the third-largest city in Sweden, after Stockholm and Gothenburg, with a population of 316,588 inhabitants out of a municipal total of 338,230 in 2018 [68]. Being perfectly situated along the straights, it separates Sweden from Denmark, and also connects Sweden to Denmark through the Öresund bridge, whose opening in 2000 made Malmö Sweden's principal point of entry. Since the construction of the Öresund Bridge, Malmö has undergone a major transformation which can be seen more clearly in Western Harbor (Västra Hamnen) than in any other part of Malmö. The Municipality of Malmö had initially invested in residential development on the site by means of a European housing exhibition focused on sustainability-Bo01, exploring a drastic vision of future living intended to provoke discussion and to be a best practice exemplar pilot project for a mixed district. This event was held in Malmö in 2001.

Bo01 represents the first step in the process of transforming the 160 hectares of Western Harbor area into a sustainable urban district. When completed, the Western Harbor area will consist of a total of approximately 11,000 homes and 17,000 jobs, and over 20,000 people will be able to live in the area [69]. At the beginning of 2014, this district had approximately 4000 homes and approximately 10,000 jobs, 
in addition to a number of facilities and services [69]. The original plan created to redevelop this formerly industrial, waterfront real estate has led to the transformation of 18 hectares into a mixed-use residential community built according to sustainable principles.

Similarly, Western Harbor is designated as an environmental profile area with the mandate to become a model of modern eco-city district. Its aim is to become an international leading example of an environmentally sound, densely populated district, i.e., with an environmentally sustainable development profile that runs on renewable resources. The development of Bo01 in 2001 was to accommodate commercial and social uses, and related housing exhibition in 2002 showcased what was achievable in terms of planning, designing, and building to the highest energy efficiency and renewable energy standards. This in turn enabled the testing of new sustainable technologies and approaches to their application on a wider scale. However, the key goal of Western Harbor is to become an environmentally sound and sustainable urban district, integrating all three dimensions of sustainability, ecological, economic, and social [69].

\section{Results: The Core Eco-City Strategies and Solutions for Achieving Urban Sustainability}

In order to identify the key dimensions of the two eco-city districts and their link to the environmental, economic, and social goals of sustainability, as well as the extent to which they produce the expected benefits of sustainability in terms of its tripartite composition, we will now take a closer look at the two districts' planning and development documents. We begin with the environment dimension of the eco-city district as an approach to sustainable urbanism.

\subsection{Environmental Sustainability}

\subsubsection{Sustainable Systems}

The environmental targets set by SRS and Western Harbor are being supported by the application of cutting-edge environnmental technologies, including sustainable energy system, smart grids, smart communications, eco-cycle waste management, biogas and electric cars, sustainable buildings, sustainable transportation, as well as sustainable lifestyles.

\section{Sustainable Energy System}

The energy system is at the core of the planning practices and development strategies for both districts. One of the key strategies for sustainable urban development underlying the sustainability program for SRS is 'resource efficiency and climate responsibility.' In this respect, the City of Stockholm [66] argues that for the built environment to be robust over time, it is required that natural resources must be used efficiently, and that buildings and facilities are designed with high quality. Renewable energy generation and use is strongly advocated to make SRS fossil fuel free, and the future energy system in SRS is intended to be based on renewable sources. In the environmental and sustainability program for SRS, it is recognized that for the district to fulfill the ambition of becoming environmentally sustainable, the energy system plays an important part [70]. The Municipality of Stockholm set these energy requirements on urban developers: $55 \mathrm{kWh}$ per $\mathrm{m}^{2} \mathrm{x}$ year and $30 \%$ locally produced electricity by renewables (Figure 2). 


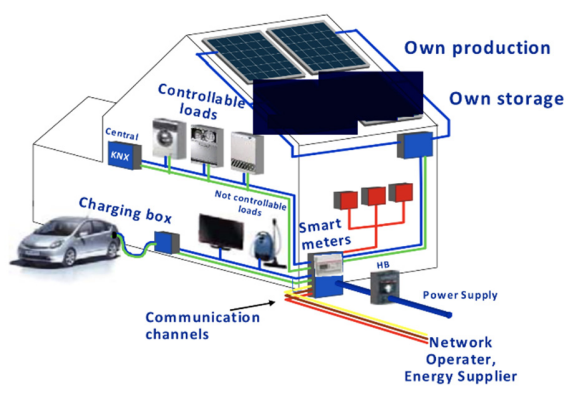

Figure 2. Local production of electricity.

Both requirements are associated with the energy goals set by SRS as shown in Table 2 .

Table 2. Energy goals of SRS.

1. Fossil fuel free by 2030.

2. Large-scale net-zero houses and locally produced solar energy-electricity by renewables (Figure 2).

3. Passive houses towards plus houses.

4. Minimization of comfort cooling/use of passive cooling technology.

5. Energy quality hierarchy (using high energy quality only when needed).

6. Low level of energy use concerning products and systems.

7. Bio-fueled combined heat and power (CHP) system, including recovery of waste/heat.

8. Measuring energy usage in all households/buildings.

9. Smart grids for electricity (and heat).

Stockholm has a strong tradition of using district heating as a well-developed, efficient system for the distribution of heating, cooling, and hot water to buildings (Werner 1989). Environmentally, Stockholm focuses on low-carbon development, most notably through widespread district heating and cooling systems (OECD 2013) [71]. The environmental and sustainability program for SRS states that the energy system in SRS must primarily be based on the bio-fueled CHP system [70], which entails local production of electricity by renewables and smart waste collecting system. Incineration of household waste is one of the main energy sources for district heating [71]. The energy requirements for the buildings in SRS are set high and will thus decrease the demand for heating in the area [70]. In this case, it is of importance to develop a flexible system in such a way that it can be adapted for use with other sources of energy as well as integrated with multiple systems. Hence, the utility provider Fortum is currently in the process of building a new bio-fueled CHP plant at its facility in Värtan, which is located in the SRS district [72]. The plant, as one of a number of ways that will make the vision of a sustainable and climate-smart urban environment become reality, will contribute to a further reduction in Stockholm's $\mathrm{CO}_{2}$ emissions by generating $10 \%$ of its electricity needs and $25 \%$ of its district heating needs [65]. As it will distribute district heating to southern and central parts of Stockholm, in addition to SRS, it will contribute to reaching the ambitious emission reduction targets set by the City of Stockholm.

As acknowledged in the environmental and sustainability program for SRS, every part of the district that is affected by the energy system, e.g., buildings and infrastructure, must be highly effective, and the goal is that SRS will become a climate-positive district [70]. The results achieved in 2017 show, according to the sustainability report for SRS [66,73], that the energy consumption was reduced by $40 \%$ in total-energy performance lower than national legislation, and actual PVs production is 1 $\mathrm{GWh} /$ year. Requirements on energy, waste, and transportation as one of the smart sustainable solutions implemented by SRS are reducing GHG emissions by approximately $60 \%$ [74]. However, developing an energy system that is not dependent on fossil fuels involves delicate challenges and developing such a system for SRS as a single district can pose even greater ones. 
The energy vision for the City of Malmö is that renewable energy sources will be phased in and fossil fuels phased out. Malmö's Energy Strategy has the goal of supporting the entire geographical area of the city with renewable energy by 2030 [75]. Energy efficient housing and sustainable buildings combined create ecological values, and investment in this area of urban ecology contributes to decreased energy resource use. Western Harbor is the 'the first climate-friendly district in Sweden' [69], and a great deal of attention in this district has been given to the use of natural resources, as well as recycled water, waste, and raw materials. Local energy production is integrated from the start throughout Western Harbor. The Bo01 area was planned to have, and is currently being served by, a $100 \%$ locally produced energy supply from renewable sources (Figure 3). This concept is based on local conditions for energy production and this equation is based on an annual cycle. In the Bo01 area, 1000 homes are supplied with energy from renewable sources: solar energy, wind power, and water through a heat pump that extracts heat from seawater and an aquifer (Malmö City 2006). Producing renewable energy, heat, and gas through wind, biomass, and sun is seen as Malmö's advantageous potential that should be used in the best manner. Renewable sources in Western Harbor, Bo01 (Malmö City [69,76] are presented in Table 3.

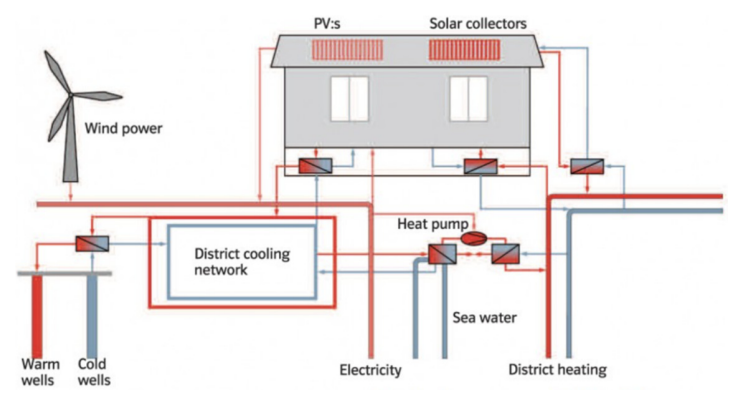

Figure 3. The Bo01 system: 100\% locally renewable energy.

Table 3. Renewable sources in Western Harbor.

- In total, $1400 \mathrm{~m}^{2}$ of solar collectors installed on the top of ten buildings with a calculated annual heat production amounting to $500 \mathrm{MWh}$. They complement the energy produced by the heat pump to supply the area.

- A large wind power station using a $2 \mathrm{MW}$ wind turbine and $120 \mathrm{~m}^{2}$ photovoltaic solar panels on the buildings to produce electricity for the apartments and homes, the heat pump, fans, and other pumps within the area. The wind turbine is $120 \mathrm{~m}$ in height when measured to the tip of the wings, with a calculated annual electricity production of $6300 \mathrm{MWh}$.

- The plants are linked to the energy systems in the city for district heating, district cooling, and the electricity grid. The solar collectors are directly connected to the district heating system, precluding the need for extra storage tanks.

- Low energy use in the buildings is a requirement, and each unit is only allowed to use $105 \mathrm{kWh} / \mathrm{m}^{2} / \mathrm{year}$, including household electricity.

Many buildings in Western Harbor have solar panels for both heat and power production. As stated in the current urban development of Western Harbor [69] (p. 14), 'There are a total of over 3000 $\mathrm{m}^{2}$ of solar panels supplying heat to the district heating network. Some buildings also have small wind turbines on the roof ... Nearly all dwellings in the Western Harbor district are heated by district heating, produced both from waste incineration and from solar energy and inter-seasonal storage in the bedrock.' The latter relates to the heat pump, which mainly extracts heat and cold from a natural underground reservoir and, to a lesser extent, cold from seawater. In the Western Harbor, there are 10 cold and warm wells in an aquifer at a depth of 40 to 70 meters placed in the ground. The water of the aquifer contains a stable temperature of $10-11{ }^{\circ} \mathrm{C}$ throughout the year and is used in the summer for storing heat and in the winter for storing cold. 
In terms of passive solar design, Fullriggaren neighborhood, which was built in 2009-2013, constitutes the greatest collection of passive and low-energy buildings in Sweden, where renewable energy is produced locally via solar panels and cells [69]. It is the third development project for housing in Western Harbor and contains as many as 200 of the 600 dwellings that are passive houses. The preliminary evaluation of this neighborhood shows that the actual energy use is closer to the target than in the first phase, Bo01, where the energy use was higher than expected [69]. As one planner confirms, 'While several of the buildings have met the targets in the Bo01 area, there was a number of them where the energy consumption exceeds the target excessively, which had led to the investigation of the issue and the continuous measurement of the energy consumption in order to improve the situation in future urban development projects.'

\section{Environmentally Smart Sustainable Solutions}

In ranking 28 European capital cities based on how smart and sustainable they are using hierarchical clustering and principal component analysis (PCA), Akande, Gomes and Cabral (2018) [77] found that Stockholm is the leading Nordic capital city in this regard. The City of Stockholm (2017) [61] sets the following targets:

To use digitalization and new technologies to make it easier for residents and businesses to be environmentally friendly;

To reduce energy consumption and carbon footprint;

To provide sustainable solutions for modern transport;

To use digitalization and new technologies to stimulate biological diversity and conservation;

To produce goods and services in a resource efficient way with minimal environmental impact.

According to the City of Stockholm, an IoT-based infrastructure is highly important and the backbone for building smart sustainable cities. As Johansson Claes (2018) [78], a project leader, states, 'the reason we are establishing this is because we have a lot of challenges. We know that using the smart technologies can help us to be a better city, for the people that live there, work there and even the people that are visiting us.' It was also stated that the environmental department in the city is active with smart technologies. The smart eco-city district of SRS starts with a common vision in smart planning and design on the basis of IoT technology [74]. It was during the period 2015-2016 that an 'ICT network' was established in the City of Stockholm to find a more comprehensive way of using ICT, and that the name of the IT department of the City was changed to 'digital development' with a much broader take on ICT (Kramers, Wangel and Höjer 2016) [48]. The telecom company Ericsson, which is based in Stockholm, was the first company to give a presentation on smart sustainable cities, which had a major effect on people in the city in terms of how the digital and physical landscapes of the city can be merged together [48].

The City of Stockholm's main domains include smart traffic, smart lighting, air pollution, and sustainability (environmental and green policies). Some smart solutions include [66]:

- BigBelly: Waste bins using solar power and packing trash automatically when needed, with notification of when they need emptying.

- Smart lighting: Sensor-controlled LED lighting for pedestrian and bicycle paths, self-controlled-LED street lights with preset lighting schedules, and remote-controlled lights.

- Green IT for reducing environmental impacts: Energy-efficient buildings (monitoring and optimization), transportation (intelligent transport solutions), and digital meetings and mobile workings.

Small-scale tests were performed within the different areas of the city to determine whether smart technologies have been converted into pilot projects within the above mentioned domains [78]. Here, the IoT infrastructure is being used to establish and share data from different projects related to traffic, lighting, air pollution, and the environment, and the role of private companies should lie in establishing new services out of these data. 
However, the strategic implementation of ICT was brought in by the environmental program for the City, which involved requirements that SRS should be smart in this direction. Therefore, the environmental targets set by SRS are being supported by the implementation of smart technologies. Among the smart sustainable solutions implemented by SRS are the establishment of digitalized monitoring and feedback processes, and triple and quadruple helix research and development (R\&D) projects (e.g., the IoT, visualization, and circular economy [74]. The use of ICT within SRS pertains mainly to its role in reaching environmental targets as part of the digital city plan for the district.

The interview showed that the database systems for collecting the environmental data were secured and being used in SRS to give feedback and inform inhabitants. The City administration established a platform that can collect the environmental data given the importance of orchestrating the plethora of different systems. In SRS, ICT solutions are used to visualize and communicate energy use pertaining to households/buildings and smart sustainable system solutions. In this context, a new framework for Smart Urban Metabolism (SUM) has been implemented in SRS as part of a R\&D project [79]. In this framework, four key performance indicators (KPIs) are generated in real time based on the integration of heterogeneous, real-time data sources, namely

(1) kilowatt-hours per square meter,

(2) carbon dioxide equivalents per capita,

(3) kilowatt-hours of primary energy per capita, and

(4) share of renewables percentage.

These KPIs are fed back on three levels (household, building, and district) on four interfaces, developed for different audiences. The long-term opportunities of SUM include enabling a new understanding of the causalities that govern urbanism and allowing citizens and city officials to receive feedback on the system consequences of their choices. The SUM model works at high temporal (up to real time) and spatial (down to household/individual) resolutions. In other words, it can, through integrating ICT and smart urban technologies, provide real-time feedback on energy and material flows, from the level of the household to the urban district as applied to SRS [79]. However, the most challenging barrier identified in relation to SUM is accessing and integrating siloed data from the different data owners, which is hard to overcome unless a significant value is perceived. Further, applying this framework at the city level has been limited by the lack of data at this scale [80]. This is one of the common challenges pertaining to the implementation of big data analytics and its novel applications in the context of smart sustainable cities [11,81].

Moreover, SRS has implemented a large-scale smart grid system, as illustrated in Figure 4.

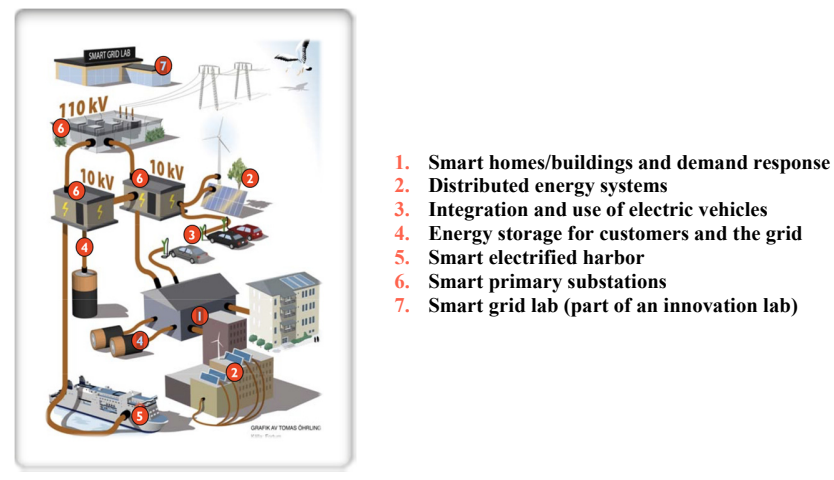

Figure 4. A large-scale smart grid in SRS.

In relation to environmental urban planning, Kramers et al. (2016) [48] address the uses of ICT in governance by improving the understanding on how the City of Stockholm administrations have worked with integrating ICT solutions for sustainability into the planning phase of SRS as a new urban 
development project. In this work, they track how ICT has become part of the environmental program for SRS and how it is conceived as regards the planning and implementation of green and sustainable technologies together with the expected outcomes. In addition, the authors identify a number of challenges for the development of SRS as a smart sustainable city district, which are summarized in Table 4 .

Table 4. Challenges for the development of SRS.

- Lack of vision as regards the digital city plan.

- $\quad$ Lack of experience with and competence in working with ICT issues in urban planning.

- Understanding the interaction between individuals and environment (i.e., buildings, public spaces, transport solutions, etc.).

- $\quad$ Stakeholder involvement and management in the innovation process.

- Long time horizon in terms of negotiating agreements for planned areas.

- Short time horizon in terms of investments due to the limited scope and time of economic analyses.

The main conclusion of the authors revolves around how ICT and sustainability as practical approaches can be merged in the planning phase of new urban development projects.

As regards Western Harbor, all homes use Internet connections to enable quick access to energy consumption data. In several properties in the Bo01 area, there are ICT solutions for reading meters and control of energy use and ventilation [76]. In addition, the property Klyvaren 1, one of the four quarters of Kappseglaren, is one of the first completely carbon-neutral blocks of flats built, and next to Klippern 2, there is a pilot project for smart energy systems [69]. Unlike the Western Harbor district, ICT solutions have, to a certain extent, become integrated in the ambitions of developing the SRS district. In fact, the sustainable systems implemented in the Bo01 area create challenges in relation to their operation and management. One architect from the Municipality of Malmö said that: 'monitoring the performance and evaluating the success of the sustainable systems continues to be challenging due to their complexity as well as cost.' It is necessary to incorporate the energy system, the waste management system, buildings and facilities, and the transport system as socio-technical systems together with ICT solutions [48] through a distributed infrastructure of computing components, resources, and interfaces that facilitate the management of urban infrastructures and services [20,21,82,83].

However, as with all emerging ICT-enabled solutions, there are several challenges that need to be addressed and overcome in terms of urban planning, design, and development. These challenges in the context of SRS involve the following:

- Sustainable long-term management of the district,

- Long-term monitoring of its metabolism,

- Silo thinking within the district administrations, and

- The transition from pilot to large-scale implementation.

Regardless, long-term commitment of the Municipality of Stockholm is uncertain when political constellations change (red-green coalition versus blue coalition), despite the promising outcome of the inclusion of ICT in the central governance of the City of Stockholm. Kramers, Wangel and Höjer (2016) [48] distill some general lessons learned as to what worked well and what did not in terms of using ICT in the planning phase of SRS as part of city governance.

\section{Sustainable Waste Management}

It is important for SRS and Western Harbor as sustainable districts to have a waste management system which enables handling waste in an accessible, safe, and environmentally sustainable manner. A key strategy in this regard is to standardize the planning of waste sorting facilities in conjunction with housing and commercial properties. Larger waste sorting stations should be evenly distributed throughout the two districts and be connected to the city's waste infrastructure. 
Waste management is an important strategy of the environmental and sustainability program for SRS. The vision is that the district should adhere to a waste hierarchy that reduces the amount of waste produced and prioritizes material-efficient products [70]. These must be re-used and recycled in terms of material and energy. The waste sorting system should be designed in a way that is accessible and understandable, and that makes it easy for residents in the SRS district to sort their waste in the correct and safe manner. Especially, a high degree of waste separation is part of the SRS goals, which implies that, for example, the household waste fraction should contain food residues and plastics [70]. The results achieved in 2017 show, according to the sustainability report for SRS [66,73], that 100\% of the properties are connected to a vacuum waste collection system (Figure 5) and 100\% of the kitchens have a waste disposal unit. SRS has high environmental sustainability ambitions, supported by the implementation of advanced technical solutions that can help to fulfill the vision. This must, however, be reinforced by great potential for behavioral change of the local residents through their engagement as part of environmental stewardship. Indeed, the residents are the actual forefront users of new technologies. One planner confirms that: 'It is up to the residents to use the waste collecting system in the correct way, as well as to adopt sustainable habits and lifestyles. Especially, the residents have no regulations to adhere to in this regard. Therefore, it is up to their goodwill and interests and the extent to which they want to live up to the vision of their district.'

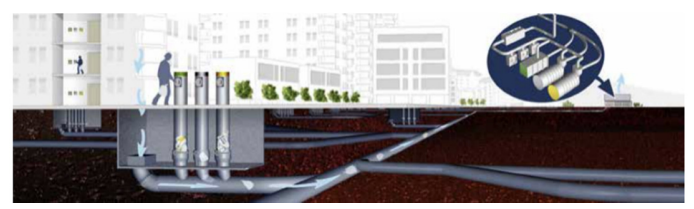

Figure 5. Smart waste collecting system.

It is also important to acknowledge wastewater and sewage fractions as important resources and, thus, to handle their integration in the sustainable energy system. This relates to the use of energy more efficiently through closed eco-cycles: solutions that do not strain the earth's resources. The SRS environmental and sustainability program states that the separation of sewage fractions must be feasible for generating biogas fuels [70]. However, concerns about the integration in question at wastewater treatment plants, coupled with the lack of ground space within the SRS area, has led to abandoning the system solutions that were proposed in the original plan for SRS and alternatively integrating them into existing wastewater systems at treatment plants in Stockholm [47]. The City of Stockholm (2010) [70] initially planned to have separate pipes for organic waste, e.g., separation of organic material from waste disposal systems and urine separation. The translation of the vision of SRS into reality has posed several challenges.

The Western Harbor district focuses on recycling, reuse, and minimization of consumption in all its cycles. In the Bo01 area, most dwellings have access to vacuum systems that are able to transport waste underground so that refuse trucks can stop outside, instead of driving into, the residential quarter to collect the waste [69]. This application involves the 147 in the Turning Torso, which have waste disposal units in their sinks that are connected to a separate collection tank from which refuse trucks can collect food waste. This new application proved to be so successful that it subsequently became standard in Fullriggaren quarter, where all 600 dwellings were fitted with waste disposal units from the start [69]. The waste management system in the Bo01 area 'was developed with the aim to create a system that minimizes the amount of waste, makes reuse and recycling possible and enables the use of waste and sewage as an energy source. Having waste separation units close to home is an important part of the planning of the area' [76] (p. 4). As part of the requirements for handling waste, it is made easy for the inhabitants in the Bo01 area to sort paper and packaging materials, as they do have a separation room in their house or close by.

All properties in Western Harbor should have access to facilities for separating packaging, food waste, and mixed waste. The City of Malmö has tried out various methods for collecting food waste in 
the district. The area of Fullriggaren is the greatest in Sweden in which organic waste is collected via waste disposal units, separate pipe networks, and collection tanks for biogas production [69]. In the Bo01 area, two parallel systems for handling food waste are tested: a centralized vacuum waste chutes system and food waste disposers in the sink [76]. With respect to the latter, the organic waste is ground and disposed in separate pipes to a collector tank underground, and the resulting sludge is taken to a biogas plant together with other organic waste and then transformed to biogas through the process of anaerobic digestion that can be used to fuel city buses and to produce heat and electricity [76]. The food waste collected throughout Malmö is also converted into bio-fertilizer that can replace artificial fertilizer on fields [69]. As regards the non-organic waste, it is deposited in one of three vacuum tubes located in the residential courtyards (Figure 5). Unlike SRS, Western Harbor has been successful in fulfilling the environmental goal pertaining to sustainable waste management, especially in relation to the energy system.

\section{Sustainable Construction Materials}

Waste is to a large extent a building issue when developing the districts of Western Harbor and SRS. Many of the materials used in modern buildings have negative environmental impacts or are associated with environmental problems, especially in the extraction and production phase [84]. A key strategy adopted by the City of Malmö is that the construction of building should be characterized by longevity and environmentally adapted materials [75]. Recycled material has been used in the underlying layers of the streets and alleys in Western Harbor, Bo01, and material in the streets and public spaces are based on the potential of future reuse and long life span [76].

Likewise, the environmental and sustainability program for SRS states that the building materials used to construct the district should be of high environmental performance, reusable, and selected using a life cycle perspective, and that the building waste should be kept to a minimum, sorted, and recycled [70]. One architect from SRS development group confirms that high requirements have been set on urban developers regarding construction materials in order to seek to acquire and develop areas in the district, which means that the operational goals of the environmental program for SRS are of high level in terms of implementation as well as maintenance. Among the smart and sustainable solutions implemented by SRS are sound and socially sustainable built-in materials and testing of innovation procurement and competition (e.g., construction consolidation center, pop-up reuse center) [74]. The ambitions for developing high-performing buildings and minimizing waste amounts as an alternative approach to construction materials in SRS gives the City of Stockholm a unique opportunity and position in this regard. Even with higher demands on the developers, construction companies have shown receptiveness and readiness to be part of the development of SRS, willing to consider new suggestions and agreeing to meet the higher requirements in set in the program for SRS, as the interview revealed. All property developers use the BASTA environmental assessment systems to comply with the requirements for construction materials [73].

\subsubsection{Sustainable Transportation}

Sustainable transportation is a key strategy for achieving environmentally sound and sustainable urban forms by means of providing services that produce environmental and social benefits and create a balance between what people need as to mobility and accessibility, in addition to environmental quality and neighborhood livability.

As a key component of sustainable transportation, the public transport system involves both the physical infrastructure, including roads, railroad tracks, sidewalks, and pedestrian paths, as well as the level and quality of services provided to citizens, e.g., great bus and train frequency and faster journey time. The public transport system in Stockholm and Malmö is seen as one of the most important driving factors for achieving the vision of SRS and Western Harbor respectively. Indeed, to achieve an environmentally sound and sustainable city district requires enhancing mobility and accessibility 
through transport infrastructure improvements. The transport system is planned to be improved by the creation of new links, enhancing existing networks, and influencing habits and movements.

In SRS, several public transportation connections such as subways, busses, trams, and ferry lines were planned and are being realized, and huge investments will be made in efficient public transport within and to SRS [65]. A metro station, Ropsten, is already in service along with several existing routes of public buses in SRS. Alongside the public transport system, important footpaths/walking tracks and bike paths/cycling lanes linking SRS to the businesses and shopping centers will be laid [65]. The SRS district is walkable and bicycle friendly and is approximately 8 to 10 minutes cycling distance to the city's Central Station. Similarly, there are plans for new cycle bridges linking Western Harbor to the inner city, and the MalmöExpressen represents a massive improvement in capacity and comfort for travel by bus to and from Western Harbor, in addition to other preparations being made for future tram links [69]. In addition, Malmö City (2015) [69] argues that as sustainable travel entails measures related to physical planning and influencing behavior, work is required on several different levels, involving both developing good physical conditions for people to choose to walk, cycle or take public transport as well as influencing behavior.

SRS is committed to, throughout its northern, middle, and southern parts, prioritizing walking, cycling, and public transport by ensuring an integrated network of pedestrian paths, cycling lanes, and parking facilities, as well as by expanding several routes of public buses and tram lines. A key strategy for sustainable urban development driving the sustainability program for SRS is 'accessibility and proximity.' In this respect, Stockholm City (2019) [66] argues that a prerequisite for transport planning in SRS is the implementation of a transport hierarchy, where walking and cycling become more convenient because of proximity to services in the local area, coupled with a clear connection between the area and a coherent urban fabric. Walking and cycling are associated with the close proximity to shops, amenities, and facilities in dense and diverse urban areas. However, the traffic hierarchy implemented by SRS is as follows [70]:

- Walking and cycling,

- Public transport (metro, buses, tram, boats),

- Car pools (biogas and electric), and

- Private cars (biogas and electric).

This traffic hierarchy and other communication patterns are meant to provide an opportunity for residents in SRS to move towards a sustainable transport system. As one transport planner confirms: 'The inhabitants in SRS have expressed commitment and appreciation for walking, cycling, and public transport, especially they are satisfied with the new improvements of transport infrastructure, and also SRS is located in close proximity to the city center.' Plans for new links and connections, good access to public transport, good availability of bicycle parking, enhanced pedestrian paths, and relevant restricted car parking that give priority to waling and cycling are the incentives that are planned to be introduced in pmissingractice as the district evolves in terms of its construction. While these incentives are crucial to moving towards a more sustainable transport system within the SRS district, the final outcome is yet to be seen, i.e., whether some parts of the plan will be abandoned or compromised.

In SRS, for example, the extension of the tramline was originally planned to be operational within the area upon the completion of the first construction phase, but this never happened during 2012 when the first residents moved into the area to the 670 new dwellings that were completed. The extension of the tramline into SRS has been delayed until 2020 [85]. However, it is important that the public modes of transportation are present within the district from an early stage in order to shift travel patterns away from private car use [86]. Otherwise, the travel habits of the residents may be affected in that they become dependent on cars for transportation. This was demonstrated in Hammarby Sjöstad and raised as a concern in the evaluation of the district as an aspect that should be improved and incorporated in future urban development projects [16]. 
Restricted parking was initially introduced in Hammarby Sjöstad, but the situation changed after pressure from the residents to match the parking allocation in other parts of Stockholm (Pandis and Brandt 2011) [16]. A growing preference among the residents to use private cars led Hammarby Sjöstad to raise its car parking spaces from 0.4 to 0.7 per apartment. Similar concerns can be raised about the car parking restrictions within SRS. Further, there is risk that residents will park outside the district, which is likely to have implications for the surrounding parts not concerned with the stricter parking regulations set within SRS (Holmstedt, Brandt and Robert 2017) [47].

Nevertheless, SRS has made special efforts targeting behavioral change among citizens as equally crucial as ensuring infrastructural provisions for mobility and accessibility within the district [66]. To further encourage residents within SRS to avoid using private cars, parking restrictions are planned whereby the parking amount within the area will be limited to 0.5 parking spaces per apartment [47]. There are also plans to provide a higher than average number of cycle parking spaces, 2.2 places per apartment [70]. The area is also planned to be connected with the rest of the city with an extension of a central city tramline [85]. Nonetheless, the newly opened highway Norra länken, which is one of Sweden's largest ever road development projects, raises the question whether it is possible to successfully implement a sustainable transport system within the area in terms of reducing car use, as the proximity to this new road can encourage transportation by car through ease of access to the road network [47].

In addition, examples of smart transport solutions adopted in Stockholm include automatic provision of priority to public transport: the use of a smart traffic light system for determining the movement of priorities of different types of transport (public transport, buses with many passengers, emergency services, etc.). By 2040, the city aims to ensure max 3 min waiting time for public transport and $100 \%$ of Stockholm public transport to be driverless [87].

Similar to SRS, the backbone of the transport system in Western Harbor, as a climate-friendly district, is walking, cycling, and public transport. The Western Harbor area is based on environmentally sound transport approach by being planned with lots of different types of services and recreation so as to reduce the need for transport, and the use of environmentally friendly modes of transport is encouraged and pedestrians and bicycles have priority in the area [76]. The public spaces, mostly closed to cars, in Western Harbor provide a range of opportunities for cycling and walking along pleasant routes. According to Malmö City (2006, pp. 3, 6) [76], 'Cars are not allowed to dominate, pedestrians rule ... Bus stops are within as distance of $300 \mathrm{~m}$ from the flats. The bus service which connects with several of the main central points in town run in seven minute intervals.' Bus ridership is in the Bo01 area about the same as the city average [88], and the distance to the bus stop is within 1500 feet, with buses operating on a seven-minute schedule [76]. As part of the city target of reducing car journeys by Malmö residents to 30\%, Western Harbor's long-term objective is for walking, cycling, and public transport to account for at least 70\% of journeys to work and 75\% of residents' journeys by 2031 [69]. In the City of Malmö, 30\% of all trips are by bicycle and $40 \%$ of trips to work or school are by bicycle [89].

Different surface areas are required for the same number of travelers, depending on the means of transport (cycle, bus, car, etc.). In this respect, the City of Malmö (2015) [69] has identified ten initiatives (Table 5) and developed strategies for how the work should be continued. 
Table 5. Ten initiatives in influencing behavior and shaping physical structure. Source: Malmö City (2015) [69].

\begin{tabular}{|c|c|c|}
\hline & Influencing Behavior, and Dialogue & $\begin{array}{l}\text { A Physical Structure for Walking, Cycling, and } \\
\text { Public Transport }\end{array}$ \\
\hline 1. & $\begin{array}{l}\text { Communicate the city's approach to transport } \\
\text { and spread information, }\end{array}$ & $\begin{array}{l}\text { 6. Cycling must be visible and prioritized, } \\
\text { 7. Short, safe and pedestrian-friendly, }\end{array}$ \\
\hline 2. & $\begin{array}{l}\text { Intensify mobility management initiatives } \\
\text { linked to companies and workplaces, }\end{array}$ & Fast, high-capacity public transport, \\
\hline 3. & $\begin{array}{l}\text { Intensify information and mobility } \\
\text { management initiatives linked to housing, }\end{array}$ & $\begin{array}{l}\text { Vehicle trattic on human terms, and } \\
\text { Multi-storey car parks as the parking solution. }\end{array}$ \\
\hline 4. & $\begin{array}{l}\text { Develop ways of providing information about } \\
\text { sustainable travel to visitors, }\end{array}$ & \\
\hline 5. & $\begin{array}{l}\text { Participate actively in developers' } \\
\text { environmental certification, }\end{array}$ & \\
\hline
\end{tabular}

Multi-storey car parks as the parking solution was proposed as a result of the concern raised in the Bo01 area. The affluent lifestyles of many inhabitants in the Bo01 area have led to higher car ownership than anticipated, which subsequently resulted in building a multi-storey carpark in the area of Western Harbor [69]. It was a challenge to determine the amount of space needed for parking, as the demand for parking was underestimated. Regardless, parking provision per household is still low compared to Malmö's average: a ratio of 0.7 versus ratio of 1.1. In addition, the City of Malmö has successfully implemented pilot projects with car and cycle pools in partnership with property owners and developers in Western Harbor, but the rentable electric car scheme was withdrawn in the Bo01 area, as the fleet that was available to residents never took off [69].

\subsubsection{Green Structure-Green and Water Areas}

The municipalities of Stockholm and Malmö operate with the concept of 'green structure' in their plans. This concept comprises larger green spaces, waterways and streams, shorelines, parks, natural and agricultural land, and forests as one common structure. Green space entails the areas of nature found in the urban landscape, and includes trees, grassy patches, water features, flowerbeds, and rock gardens. Stockholm is a city with abundant green and water. Over $90 \%$ of Stockholm's population live within $300 \mathrm{~m}^{2}$ of a green area, and over 10\% of Stockholm's surface is water [61]. Green zones and parks represent $40 \%$ of the City of Stockholm [67].

SRS is located between the inner city and nature [65]. A key strategy for sustainable urban development underlying the sustainability program for SRS is 'let nature do the work.' In this regard, in the planning process for SRS, multi-functional green structure has been designed 'to provide important ecosystem services, such as flood protection, temperature regulation, recreation, and biodiversity. Parks, courtyards, and other spaces form a green structure that helps to create a more resilient urban district' [66]. According to the sustainability report for SRS [66,73], the results achieved in 2017 in connection with the strategy in question are presented in Table 6:

Table 6. The achieved results of the green strategy in 2017.

- In total, $100 \%$ of apartments have access to a park and natural environment within 200 meters.

- In total, 5.5 ha of parks has been built and divided between 2500 apartments.

- In total, there are 447 newly planted trees and 25 tree species.

- In total, there is $13.500 \mathrm{~m}^{2}$ of green roofs, which corresponds to two football fields.

- In total, there is $29.500 \mathrm{~m}^{2}$ of green courtyards, which corresponds to four football fields.

- $\quad$ Parks correspond to seven football fields. 
A great deal of attention in Western Harbor, Bo01, has been given to highly diverse green spaces and biodiversity. Rainwater is diverted through aboveground gutters surrounding each building as part of public space design, and the drainage system is designed to be aesthetically pleasing, with waterfalls, canals, ponds, and various elements for purifying and buffering the water. Rainwater travels through green roofs, into ponds in the courtyards, where it is partially cleaned by the ora, and public spaces and is then transported into open canals along the streets to run out into the sea [76]. Rainwater is not channeled in pipes under the ground, i.e., cannot infiltrate into the ground. The green roofs help reduce the amount of rainwater to be drained. As stated by Malmö City (2015, p. 14) [69], 'the journey of the rainwater begins up on the roofs, where it is slowed down by green roofs, a smart solution used on many roofs in Western Harbor.' The objective set by Malmö City (2015) [69] is for all service water to be dealt with locally on site, and the area is moreover designed to deal with climate change and heavier rainfall in the future.

The City of Malmö uses what is called 'green space factor,' a planning instrument introduced in 2001 in connection with the Bo01 housing fair that guarantees a certain volume of greenery in residential courtyards. This instrument is now being used in the city's new construction projects. The General Plan for Malmö states that, 'Green space factor is a tool for ensuring that green qualities are achieved in connection with construction. Green space factor can be used where appropriate and can be developed to be more applicable in different contexts. The aim is to contribute to good living conditions for humans, animals and plants'. A green space factor system ensures that the solution should involve not only the greening of the inner courtyards with plenty of vegetation and ponds, but also green roofs and climbing plants on the walls (Malmö City 2006) [76]. The positive contribution to the urban environment made by the greenery and water resulted from the application of green space factor pertains to ecosystem services, such as recreation, reduced risks of flooding, improved local climate, and noise reduction [76]. The General Plan states that: 'Ecosystem services must be valued, taken into consideration and reinforced in urban planning, maintenance, and management so that their values and functions do not deteriorate'. Furthermore, to promote biodiversity in Western Harbor, green space factor is supplemented with 'green points,' a list of 35 wide-ranging environmental measures were implemented in Bo01—at least 10 of which were to be implemented in every residential courtyard-e.g., bat nesting boxes, butterfly flower beds, country gardens, soil depth to grow vegetables, and so forth $[69,76])$. Surveys of the residents indicate, as stated by Austin (2013, p. 49) [90], 'great satisfaction with the neighborhood and the units with the exception of some consternation about a presumption by the citizens of Malmö that public funds were expended to provide facilities for wealthy residents'.

In both SRS and Western Harbor, green areas are valued highly and recognized as important for the preservation of nature's own integrity as well as a significant recreational factor for the inhabitants of the districts. Green space is particularly associated with health and recreation as part of the quality of life. As stated by Malmö City [76] (p. 3), 'research shows that close contact with green areas, sun, and water make people healthier, both physically and mentally. Beauty ... also has a proven positive effect on health. These research results were all taken into account by the planners.' One local planner from Stockholm Municipality said, 'Green space is highly appreciated in the local area due to its health and recreational benefits, and the SRS diverse greenery and water features are increasingly attracting people to settle in the district.' The SRS area is surrounded by perfect green and water view. It lies next door to the Royal National City Park. So, it is being developed in direct proximity to Stockholm's only urban national park, which is classified as a protected area both with regard to its specific and sensitive flora and fauna and to its cultural heritage [91]. It also runs along the waterline of the Baltic Sea. It is being transformed into a livable waterfront district, providing favorable conditions for residents to live and work in good health and with the quality of life. One of the goals of the plan for SRS is to use the waterfront footpath and railway park as linkages to several landscape nodes. The waterfront area offers plaza, green space, park, and promenade, allowing for a variety of activities to take place. According to one expert in SRS development, 'the waterfront area provides great opportunities and its offerings are crucial to encourage social mix of residents and social interaction, as well as a mixed use 
of functions. Therefore, the planning aims to enhance accesses to this area given the radial layout of urban form.'

\subsection{Economic Sustainability}

Generally, while the environmental concerns remain a key driver of the eco-city projects and initiatives, they are also mobilized in the pursuit of economic ends. Indeed, economic aspects and issues in SRS and Western Harbor are of particular emphasis as the districts seek to be a vehicle for developing new renewable energy and energy efficiency technologies, as well as to be attractive and vibrant as built environments. Accordingly, environmental sustainability is perceived as a source of economic development. The plans and publicity materials of SRS and Western Harbor projects led by the state and private sector actors contain innovative technologies and ambitious targets, attractive designs, modern architecture, and green areas and parks for recreation to advertise their 'eco-ness.'

\subsubsection{Mixed Land Use and Attractiveness}

Land use refers to the distribution of functions and activities across space, grouped into different categories. Widely recognized for its important role in achieving sustainable urban forms, mixed land use denotes the diversity and proximity of compatible land uses, a form of cross-sectional residential, commercial, institutional, and cultural infrastructures associated with living, working, and service and amenity provisioning. As a preferred typology in sustainable urban planning and development, diversity, which overlaps with mixed land use and the variety of land uses, entails building densities, housing for all income groups through inclusionary zoning, a variety of housing types, job-housing balances, household sizes and structures, cultural diversity, and age groups, thereby representing the socio-cultural context of the compact city. Indeed, diversity has been used interchangeably with social mix (i.e., housing types and options, demographics, lifestyles, etc.) in the literature. The mixed land use and social mix approaches are an important part of the planning and development strategies of SRS and Western Harbor, aiming towards a lively and long-run sustainable city with a balance between environmental, economic, and social factors. As supported by one architect from the Municipality of Malmö, 'the diversity of functions and architectures of the district gives a good base for services, retail trade, and public transport, and also induces people to live and work in the area.' One expert of SRS development said, 'mixed-land use has not only economic benefits of sustainability, but also environmental and social benefits through sustainable travel behavior and equal access to services and facilities respectively.'

Strong support for the sustainable development advantages of a diverse and vibrant built environment-a mixed-use city-is well reflected in a series of debates with politicians and experts and open community meetings with respect to Stockholm and Malmö's future and key urban development initiatives $[67,75]$. This is expressed relatively in the same manner as to SRS and Western Harbor (Table 7). 
Table 7. Mixed land use features in SRS and Western Harbor.

\begin{tabular}{ll}
\hline \multicolumn{1}{c}{ Districts } & \multicolumn{1}{c}{ Mixed Land Use Features } \\
\hline A key strategy for sustainable urban development underlying the sustainability \\
program for SRS is 'vibrant city' (Stockholm City 2009) [65]. \\
The program for SRS aims at a mix of housing, offices, shops, amenities, and \\
public services and facilities combined with well-designed, varied public \\
spaces—streets, parks, and squares-as important meeting places that create \\
conditions for a lively atmosphere between the buildings [66]. \\
It was planned that: 'Quayside walkways will be laid out along the port areas, \\
with offices, restaurants, bars, and shops [in addition to conference centers, \\
theaters, gyms, and hotels] helping to create a mixed urban development full of \\
life and activity ... The dynamic of the city will be reflected in the diversity of \\
living accommodation and the range of amenities, culture, and entertainment. \\
Housing, amenities, and public spaces will be distinguished by accessibility and \\
modernity' [65] (pp. 16, 18). \\
$\begin{array}{l}\text { Western Harbor is 'a district with a mixture of housing, services, industries, } \\
\text { workplaces, education, and recreation. The district has a unique, attractive } \\
\text { location with urban and natural features; it is within walking distance of the inner } \\
\text { city, has good transport links. ... By continuing to develop these qualities and } \\
\text { building a mixed city, it will be possible to link Western Harbor to the central } \\
\text { parts of Malmö' [69] (p. 9). }\end{array}$ \\
\hline
\end{tabular}

An attractiveness discourse prevails in SRS and Western Harbor and is strongly linked to mixed land use and diversity. Creating an attractive and safe district with vibrant life is thus one of the key goals of the planning strategies for the two districts. A set of statements describing attractiveness and safety from the Master plans for the two districts is presented in Table 8.

Table 8. Attractiveness and safety in SRS and Western Harbor.

\begin{tabular}{ll}
\hline \multicolumn{1}{c}{ Districts } & \multicolumn{1}{c}{ Attractiveness and Safety } \\
\hline A variety of spaces is planned in SRS-intense, peaceful, and quiet settings, and \\
busy walkways (Stockholm City 2019) [66]. \\
SRS entails 'a diverse offering of homes and office space [that] will attract a \\
multitude of inhabitants and businesses ... Diversity leads to freedom of choice. \\
People living in the district will be able to select welfare services to meet their \\
needs and requirements, SRS will have space for everyone' [65] (p. 23). \\
The results achieved in 2017 show, according to the sustainability report for SRS \\
[66,73], that 91\% feel safe in SRS compared with an average of 71 percent for the \\
City of Stockholm. \\
The amalgam of land use forms a network that connects both internally and with \\
surrounding areas, favoring of safety [66]. \\
One planner from Malmö Municipality said, 'Greater diversity gives a district life \\
that is attractive and creates a feeling of security'. Western Harbor strives to \\
provide a safe district where people feel a sense of belonging and security, with \\
access to services and public spaces and thus opportunities to meet. \\
'The urban environment should offer natural meeting points and a well-balanced \\
mix of housing, activities, education, service, and green areas. Human needs for a \\
variety of sensory impressions like beauty, human proportion, nature, water, \\
contact, and safety should be met' [76], (p. 7).
\end{tabular}

Accessibility is a crucial aspect in encouraging social interaction among the local inhabitants, and access to everyday commodities within a walking distance is a key issue in both Western Harbor and SRS. Both districts strive to provide greater opportunities to manage daily life on foot, by bike, and by public transport thanks to the proximity to shops, services, facilities, and workplaces. This reduces the needs for long-distant transport, as more errands can be run by walking, cycling, or public transport, and more people will have an easier day-to-day life. Both districts highlight their commitment for 
prioritizing infrastructure provisions for walking, cycling, and public transport, and also set parking standards-cars per apartment unit and bikes per apartment. One of the smart sustainable solutions implemented by SRS is street spaces for pedestrians, cyclists, and public transport with appropriate infrastructure for electrical vehicles, car pools, and bicycle parking [74].

\subsubsection{Business Development}

Sweden ranks in the top two in the European Union Innovation Union Scoreboard, and Stockholm's national competitiveness and performance is very high. SRS as a new urban district is one example that reflects the measures the City of Stockholm is taking to attract investments, business ventures, and visitors, especially in relation to green technologies and innovative solutions. The vision of Stockholm is to be, by the year 2030, a world-class dynamic and innovative economy that successfully competes with products and services in the global marketplace, and that is characterized by knowledge-based businesses; high innovation; and unique collaboration between businesses, educational institutions, and research facilities [65].The City of Stockholm's green-tech, innovation-led, diversified economy is a result of a long-term and wide-ranging approach to Swedish economic development that involves partnerships between government, academia, and industry. Stockholm improves the environmental performance towards the low-carbon economic development, which has made it a green economy pioneer. It is one of the world's cleanest capitals in the world and has a long history of environmental work. It was the first city to be granted the European Union's Green Capital award by the European Commission in 2010 [62] because of its high environmental standards and ambitious goals for further environmental improvement, to reiterate. In addition, Stockholm demonstrates high economic growth along with a high employment rate. The financial component of Stockholm Smart City strategy includes the following [87]:

- An attractive, innovative and growing city, with the perspective of making an investment or establishing a business;

- A central node in a global network of successful cities;

- One of the best start-up scenes in the world;

- Develops and grows through entrepreneurship and intrapreneurship in digitalization and new technologies;

- Attracts talent and visitors, both international and national;

- Manages its public operations cost efficiently by making full use of digitalization and new technologies.

\section{Green and Environmental Innovation}

One of the strengths of the SRS project in terms of the environment that gives it an advantage over other projects lies in cutting-edge green-tech innovations. SRS is expected to contribute substantially to the economic growth of Stockholm's potential as an innovation hub (with Ericsson, ABB, Fortum, and Electrolux). The two main economic growth sectors in SRS are the innovation sector and the services sector. With respect to the former, in particular the innovation center for sustainable technology, the sustainability initiatives will become the focus point for the district to showcase the sustainable development lifestyles. As to the latter, which remains specific to the district and thus may not be generalized to other eco-city districts, the cruise port is expected to expand the tourism industry and related services, as well as to boost regional business links. This aspect relates to the argument that cities and districts are fully dependent on the surrounding environments.

SRS aims to take the lead in realizing the latest innovations within environmental technology and sustainable development, and affords particularly great opportunities for climate-adapted and future-oriented development, from pioneering energy-efficient technical solutions in building and infrastructure to the development of smart electricity networks that enable local production and distribution of electricity [65]. According to the environmental and sustainability program for 
SRS [70], the innovation center in SRS will feature the latest developments in clean and environmental technologies and show how related solutions are being tested and applied, and SRS will serve as platform for presenting the area to the public and interested parties and an important showcase to the outside world. It will also serve as an international meeting place where the city, the business community, and research institutions work together to profile and demonstrate Swedish know-how in urban sustainability. The formal organization in the SRS project works in parallel with the SRS Innovation Arena, which involves industry experts, businesses, and citizens, to build up practical knowledge [48]. However, looking at the economic growth achievement of Hammarby Sjöstad, the project has provided opportunities to many development and construction companies as well as benefits to green-tech companies, and also the new green-tech and skills developed for the site have been exported to wider markets in Sweden and abroad.

The transformation of Malmö from a typical industrial city to knowledge city can be seen more clearly in Western Harbor than in any other part of Malmö. The old shipyard area has become Malmö's new center for IT companies, and many high-tech, knowledge-intensive service companies have moved in the area (Malmö City 2015) [69]. The proximity between companies and Malmö University and its innovation centers in the Western Harbor area means that partnerships between these are well established. There are also innovative industries such as MINC (Malmö Inkubator), Cleantech City, and MECK (Media Evolution City) in the area. There exist approximately 300 companies in the area that together employ approximately 8000 people [69].

A great deal of the positive experience gained from the development of the initial site of Bo01 is of economic nature, especially the success of the Bo01 Project as a marketing tool for the City of Malmö in terms of attracting new investments, ventures, and international interests. Bo01 is a well-known internationally leading example of sustainable urban development, and an initiative that has received a number of awards, attracted study visits from all over the world, and been extremely important to the local work for ecologically sustainable urban development in the city of Malmö [69]. It has been a catalyst for attracting further development initiatives in the city, and much has been learned from it that is directly being applied to further development in the Western Harbor area. The district's planners have created an unusual laboratory, resulting in an exceptionally pleasant district thanks to clean technologies and the great deal of architectural diversity without the usual restrictions. These aspects have made the area an example for other urban development projects in Sweden and in other parts of the world [69]. Proved additionally to be a success is the incorporation of green components in the individual projects beyond basic landscaping, as well as the collaboration on and achievement of a shared vision of sustainability among companies, organizations, and institutions with different goals and interests.

\section{Research and Development and Public and Private Partnerships}

Another related dimension of economic sustainability is research and development (R\&D) opportunities created in light of the planning, development, and management of SRS in the medium and long term. There are $20 \mathrm{R} \& \mathrm{D}$ projects (e.g., the smart grid project, ICT for sustainability, climate+ development program, sustainable lifestyles project, evaluation model research program, etc.) currently active, which are conducted in collaboration with the academic community, research institutes, and businesses [66]. There is strong synergy among public and private sector, including the industry community and research institutions to finance innovations, and a robust social capital and trust in district governance. In their article 'Governing the Smart Sustainable City: The case of the Stockholm Royal Seaport,' Kramers, Wangel and Höjer (2016, p. 108) [48] state that the SRS project 'represents the joint collaboration effort of citizens, construction developers, waste, water, and energy utilities, as well as the city departments, to meet the vision of real-time feedback as outlined in the city's sustainability program for the SRS.'

Research is key in the development of Western Harbor since Phase 1 2001, the Bo01 Project, in terms of scientific evaluation related to urban sustainable development and the use of results in future 
projects, both locally and in other parts of the world [76]. The evaluation work pertaining to Bo01 involves 10 universities and colleges, and the area receives study visits from all parts of the world. A key part of such work includes the infrastructure and function of the technical systems, including waste disposal system and energy supply, as well as the perception of housing and surroundings by residents [76]. Like SRS, there is a number of ongoing research studies within all areas of priority: traffic, energy, green structure and storm water, building and living, recycling, environmental information and education, and sustainable development [76].

The Line-Atlas Project entails an attractive urban environment that promotes innovation, research, development, interaction, and economic growth. It is an urban development project that focuses on modern workplaces in a networking city. It extends between Central Station and Dockan and comprises more than 300 businesses and institutions, 6000 employees, and 10,000 students in a business community that is already active [69]. With this project, businesses and workplaces are promoted by developing urban life, urban space, and urban environment. According to the updated plan for Western Harbor [69], the vision is to create the most attractive, modern workplaces; the world's most innovative business environment; and a strong community of businesses, institutions, and employees. In addition, the Line Project emphasizes the individual business and the community—sharing economy—by using and transforming premises, buildings, and spaces, and also examines the development opportunities along its route, meeting places, and other urban facilities [69]. In fact, the city district's increasing population creates a need for more workplaces and housing, and this population makes use of the supply of businesses, services, and facilities.

\subsection{Social Sustainability}

Much of the literature on the City of Stockholm points to its greater focus on the environmental and economic goals of sustainability than the social goals of sustainability. The planning practice in Stockholm gives greater priority to ecological sustainability than to social sustainability [91]. The social goals are merely general descriptions and usually represented in eco-district strategies on a discursive level. The strong emphasis on the environment and economic dimensions of sustainability is indeed clearly reflected in the environmental and sustainability program for SRS ([66,70]). This indicates unequal attention to social sustainability goals. Conversely, the social, economic and environmental goals of sustainability are at the core of the continued development of Malmö, and the city strives to balance between the three dimensions of sustainability. As stated by Malmö City (2014) [75], 'Social divides in Malmö are to be healed and the city united-barriers are to be broken and inequalities are to be reduced through considered social investment. In the same way that we invest in the physical infrastructure then we must invest in Malmö's human capital.' The outcome of the holistic approach to sustainability adopted in the Bo01 Project was the quality of aesthetics and social opportunities, and the project supports human, psychological, and physical health through ready access to open space, walkability in neighborhoods, and social interaction [90].

\subsubsection{Physical Planning and Social Interaction}

Physical planning can contribute to a more socially cohesive district. Therefore, Western Harbor's vision and planning policy promotes diverse and mixed-use patterns to reduce socio-economic segregation and increase livability. The outcomes of the Bo01 project entailed outstanding aesthetics in the plan and the individual and green components, as well as spaces that foster social interactions at the block, neighborhood, and city scales [90]. Many social spaces are designed within a diverse landscape, as approximately 50\% of the Bo01 area is open space. Malmö City (2014) [75] argues that the physical environment as a framework for social interaction is a basic condition of life in the city, as spatial arrangements and designs affect the movements, residential patterns, and habits of citizens. In other words, a sustainable district must provide opportunities for people to interact with each other and carry out cultural activities through varying interior open spaces caused by the structure and the social interaction. The City of Malmö aims to create an exciting structural mix of individually 
designed streets, pedestrian walks, alleyways, and open squares in the area of Western Harbor [76]. In connection with the continuous development of Western Harbor, the city moreover aims to create an urban environment with a well-balanced mix of housing, activities, education, service, and green areas [76].

One way of evening out existing economic and social differences in both Western Harbor and SRS is ensuring that all parts of the districts have good physical links within and between the parts. As stated in the Comprehensive Plan for Stockholm City, neighborhoods will be linked and physical barriers isolating certain areas will be removed by developing new areas, improving public transportation, and providing more public spaces [67]. The development strategy aims at a closely connected district using physical planning as a tool. Similarly, Malmö City (2014) [75] states that links must be forged between the communities in different part of the city to heal a segregated Malmö, and argues that the barriers will be lifted and mental distances reduced by redesigning trunk roads and other main roads into urban high streets.

\subsubsection{Social Cohesion}

Although social cohesion is a multi-faceted process, in this context, it entails task relations, perceived unity, and social engagement. In particular, involving local communities in planning and decision-making processes is significant for residents to have a say in the development and management of SRS. Giving voice and influence should be done before and during the planning stage. According to the program for SRS, local people and some potential residents will be invited to attend a series of planning workshops, e.g., exploration of strategic options and community planning sessions. In terms of the results achieved in 2017, as stated by Stockholm City [66,73], the digital dialogue in Värtahamnen engaged 750 participants and over 100 suggestions were received, and 350 people attended a capacity development seminar in 2017 and approximately 1100 people since the start. In SRS, there has been a citizen network dialogue with information dissemination concerning different issues. Including people in consultation and idea-generation processes is an effective approach to hear their voice and then consider their advice and manage their concerns. As stated by Kramers, Wangel and Höjer (2016) [48], the intent of the dialogue processes adopted by the municipality to create an active dialogue with the citizens is to gather input on their needs and demands, which in the case of SRS focus more on bus timing, playgrounds for the children, parking lots, the reliability of different ICT systems (e.g., parking meters), and mobile coverage indoors.

\subsubsection{Citizen Participation}

One of the key strategies of sustainable urban development underlying the program for SRS is 'participation and consultation.' This is of crucial importance for improving social cohesion. In this respect, Stockholm City (2019) [66] argues that the sustainable city can only be created by cooperation between residents and businesses, the city's administrations and companies, property owners, academia, and other stakeholders. These parties are engaged and invited to take part in dialogue in order to shape and manage SRS together, especially residents, as in any planning process. However, the interview revealed that there is a lack of structures for collaboration between different stakeholders in SRS within the city departments. It is vital that all the involved stakeholders have willingness and interest in collaborating and understanding their role, especially from a holistic perspective, as the planning and development of a new district engage numerous stakeholders that need to be aware of the overall end goals in order to avoid counterproductive decisions and related consequences [47].

\subsubsection{Socio-Economic and Spatial Segregation}

From a critical perspective, currently, there is a division into 'immigrant' and 'native Swedish' populations in the Cities of Stockholm and Malmö, coupled with the persistent socio-economic spatial segregation, which is highly problematic. Stockholm has segregated residential areas, where some 
city districts are predominately inhabited by people with low socio-economic status, while others are inhabited by people with higher social status and income [67]. Also stated in the Comprehensive Plan for Malmö is that the city is partly characterized by segregation and social disparity, manifested in the large differences in living standards and public health between different city districts [75]. The city is working on and investing in breaking these trends in order to unlock the full potential offered by the city's population and cultural structure, nevertheless.

There are housing shortages and unfordable prices in SRS and Western Harbor, and excessive regulations slow housing development, market-oriented rent setting in the Cities of Stockholm and Malmö. Even though the two districts continue facing housing shortages, their development has been going on in slow pace. The interview revealed that there was a lack of affordable housing incorporated in the site of Bo01, and the residents had to cope with hefty heating bills because the dwellings have large areas of glass. The energy efficiency goals set in Bo01 were not met because the energy budget of the proposed buildings was not calculated properly. Further, the cost of the residential units was one of the missteps of the Bo01 Project, being too high to serve low- and moderate-income residents, and the increased demand for living in Bo01 lead to a double increase in the prices of the units until 2007. As a consequence, the residents of Bo01 constitute a homogenous group-healthy, white residents, notwithstanding the Bo01 project's aim to create mixed forms of housing to reduce the risk of segregation (e.g., ghetto formation) [69]. Regardless, as one local planner said, 'the lack of diversity is due to the unfordable housing prices in the district, e.g., a price of a flat is more than twice the national average price. Nonetheless, the city of Malmö has been working on developing Bo02 with greater affordable housing.' Typical of the City of Malmo is a mix of residents of various socio-economic level precluded by the cost of the residential units in the Bo01 area [90]. In connection with the continuous development of Western Harbor, the City of Malmö (2006) [76] aims also to create housing of mixed forms, providing different people with the opportunity to settle in the district. Indeed, tenant-owner flats and rented dwellings have been added to the recently developed areas, with a planning focused greatly on safety and security aspects via the design of meeting places [69]. There are three recent development projects for housing in Western Harbor concerned with housing mix [69]. These are presented in Table 9.

Table 9. Development projects for mixture of housing in Western Harbor.

- $\quad$ Flagghusen consists of 626 dwellings—of which, $62 \%$ are rented and the rest are tenant-owner flats.

- Fullriggaren comprises approximately 630 homes, and $85 \%$ of dwellings are rented and the remainder are tenant-owner or owner-occupied flats.

- Kappseglaren comprises approximately 320 dwellings. $70 \%$ are rented and the remainder are tenant-owner flats or owner-occupied flats.

\section{Discussion}

The findings showed that the eco-city district models of SRS and Western Harbor involve mainly design and technology, supported with behavioral change, as key strategies and solutions for achieving urban sustainability. Design encompasses greening, passive solar houses, sustainable transportation, mixed land use, and diversity. And technology comprises green technologies, energy efficiency technologies, and waste management systems. Design contributes to the three goals of sustainability, and technology contributes mostly to the environmental and economic goals of sustainability. Behavioral change is associated with sustainable travel, waste separation, and energy consumption.

Taking the above into consideration, the eco-city district model entails an integrated set of urban-ecological proposals supported by land use, environmental, economic, social, and institutional policies that is directed towards managing urban spaces to achieve sustainability. The eco-city district model as practiced by SRS and Western Harbor is justified by its ability to contribute, albeit not equally, 
to the environmental, economic, and social goals of sustainability. This corresponds to the results obtained from other studies (e.g., [17,43,92]). Furthermore, at the core of the eco-city district model is the clear synergy between the underlying strategies in terms of their cooperation to produce combined effects greater than the sum of their separate effects with regard to the benefits of sustainability as to its tripartite composition. For example, behavioral change facilitates waste management collecting system, which in turn affects the output of the bio-fueled CHP system and thus save energy, e.g., electricity produced locally by renewables, for other uses. Further, the availability and quality of the public transport infrastructure is a determinant factor for mixed land use development projects, which in turn contributes to creating urban environments full of social vitality and economic activity, as well as to improving infrastructural provisions for public transport.

Concerning environmental sustainability, the two city districts aim to conserve energy and decrease the demand for it through renewable sources-sun, wind, and water, bio-fueled CHP system, passive solar houses, energy efficiency processes (smart grid), and waste management systems; to reduce material resources through sustainable construction materials and waste management processes; to decrease travel needs and shorten distances through sustainable transportation, namely walking, cycling, public transport, and car pools; and to reduce the pressure on green areas, ecosystem services, and biodiversity through green structure and green factor planning tools. This is consistent with the results from other studies (e.g., $[9,16,47,90])$.

The energy sector-including transport-produces the largest share of the world's emissions of greenhouse gases (GHGs). Therefore, when the energy system is based completely on renewable resources, coupled with passive solar design (sustainable buildings), smart technologies (energy efficient buildings), sustainable waste management and transportation, the reduction of emissions is very significant. This bold strategy will make it possible for the two city districts to become climate positive, and also pave the way for phasing in renewable energy sources and phasing out fossil fuels and potentially support the entire geographical area of the Cities of Stockholm and Malmö with renewable energy by 2030. In regard to passive solar design, many studies have demonstrated and discussed its environmental benefits (e.g., [6,93-96]) related to building heat gains and losses, warming and cooling pressures, heat storage and discharge, emissivity, air and noise pollution reduction, and so forth. Concerning waste management, Marcotullio (2007) [97] argues that sustainable systems create the infrastructure to naturally process sewage waste, grey water, and storm runoff on site, in addition to preventing flooding on the urban hardscape and utilizing wastewater to fertilize and water gardens. Further, the eco-city manages an ecologically beneficial waste management system that promotes recycling and reuse to create a zero-waste system [9].

In relation to sustainable transportation, when the collective transports are powered by electricity that is produced by biofuel or solar energy, the reduction of emissions is significant. Transport is the greatest issue for environmental debates related to urban form (e.g., [6,98,99]), and is key for achieving the status of the eco-city [100]. Of importance also is the concentration of functions and activities in the two city districts that serve to, in addition to fortifying the economy, reduce the car use in favor of public transport and bike use. However, in order to implement the use of collective modes, more holistic strategic policies have to be put in practice to discourage car use. This should go beyond the increase in parking levies, the reduction of parking spaces, the increase in road pricing to make car use less attractive to include concrete incentives from public transport and bike use, travel behavior influence, and mobility management. As regards the advantages of sustainable transportation, it operates the transport system at maximum efficiency, provides favorable conditions for energy-efficient forms of transport, limits $\mathrm{CO}_{2}$ emissions, allows equitable accessibility to services and facilities, promotes renewable energy sources, decreases travel needs and costs, minimizes land use, and supports a vibrant economy [101].

With respect to greening, green space has the ability to contribute positively to key agendas of sustainability in urban areas [102]. It provides recreational opportunities, ameliorates the physical urban environment by removing $\mathrm{CO}_{2}$ emissions and other toxins from the air, enhances the aesthetics of urban 
areas and thus make them more pleasant, increases the urban image and economic attractiveness, helps to control storm runoff, creates the conditions for more ora and fauna, and enhances biodiversity [101]. However, green space has been a subject of debate when it comes to the development and redevelopment of urban areas. In this respect, the argument that the urban form will reduce the pressure on green areas, ecosystem services, and biodiversity is less certain. While the goal of protecting large green areas outside the development areas finds support in the two city districts, it is more uncertain when it comes to green areas located in or close to the urban fabric given the potential enticing opportunities for the new development projects to strengthen the economic goals of sustainability through eco-city strategies. In relation to this, SRS is being developed in direct proximity to the Royal National City Park, a protected area as to its specific and sensitive flora and fauna and to its cultural heritage [103]. The concern that the park as a sensitive area would be exposed to degradation in terms of quality and land [103] has been incorporated into the environmental program for SRS [70]. However, the issue of redeveloping this land is not discussed within the program, and it is important to consider an alternative approach that can assist in safeguarding the flora and fauna [47].

Furthermore, the two city districts tend to exhibit some differences in the way they practice ecological urbanism, especially in terms of sustainable systems and greening. This is due to their physical, architectural, geographical, historical, as well as socio-political specificities, which shape eco-city planning practices and development strategies. Indeed, there are great differences between cities in terms of their urban form as to its key constituting elements (e.g., [104]), as well as in terms of their ecological ambitions (e.g., [30]). Moreover, in their study, which aims to uncover the diversity underneath the various uses of the eco-city as a concept and to determine the extent of divergence in the way the eco-city projects conceive of what an eco-city should be, Rapoport and Vernay (2011) [17] conclude that there is a great deal of diversity among the projects considered to be eco-cities, and argue that it is better to think of the eco-city as an objective which can be achieved through various ways. This implies that there is no single vision for an eco-city district, and that the local opportunities and constraints need to be addressed in a more integrated approach.

On the whole, the focus in the two city districts is on the use of technology and design as main solutions to reach environmental targets. Production focused solutions incorporate technologies to generate renewable energy, and consumption focused solutions use smart technology and passive solar houses to decrease the demand for energy resources. This is consistent with the results from other studies (e.g., [16,17]). Additionally, the inhabitants in Western Harbor and SRS are encouraged to change their behavior to live more sustainably, and in this context, making sustainable living effortless for residents is key. The latter is in agreement with the results from other studies (e.g., [16,17]). Still, a more focused people-oriented approach should be adopted through encouraging more active engagement among the local residents and involving them at the stages of monitoring the implementation of environmental targets and standards. There is much for SRS to learn from the experience of Hammarby Sjöstad, which has mainly focused on technology-oriented innovations and less on behavioral change of the local residents, who are actually the forefront users of green technologies. As a result, the district has been less successful in fulfilling its previous energy efficiency goal of $60 \mathrm{kWh} / \mathrm{m}^{2}$, forcing the city to adjust the standard to $100 \mathrm{kWh} / \mathrm{m}^{2}$ in 2005 [16]. All in all, the behavior of individuals has become a key facet of environmentally sustainable development.

Of particular importance to highlight as to the technology strategy, especially in regard to SRS, is the role of ICT in reaching environmental targets by lowering energy use and GHG emissions through the optimization of urban systems and services, as well as in environmental planning by enabling more collaboration between diverse stakeholders and empowering citizens. This entails implementing a number of smart approaches pertaining to energy, environment, transportation, and governance. This is consistent with the findings and conclusions from other studies (e.g., $[11,12,19,23,82,83,105-108]$ ). There is a wide recognition that advanced ICT constitute a promising response to the challenges of sustainable development due to its tremendous, yet untapped, potential for solving environmental and socio-economic problems. Indeed, a recent research wave has started to focus on smartening 
up sustainable urban forms by amalgamating the landscapes of and the approaches to sustainable cities and smart cities in a variety of ways in the hopes of reaching the optimal level of sustainability $([2,3])$, especially through promoting the 'eco-city' and 'sustainable city' initiatives in their more recent data-driven smart incarnations. Many urban development approaches emphasize the role of big data technologies and their novel applications as an advanced form of ICT in improving sustainability (e.g., [20,21,106,109-111]). Therefore, the field of sustainable urbanism needs to extend its boundaries and broaden its horizons beyond the ambit of the built form and ecological design of cities to include technological innovation opportunities and computational capabilities by unlocking and exploiting the tremendous potential of advanced ICT for advancing sustainability.

With respect to economic sustainability, the two city districts promote mixed land use and diversity as design strategies to improve economic development. Specifically, they aim at a mix of housing, offices, shops, public services and facilities, and amenities combined with public spaces to achieve a vibrant city, full of life and activity. There is a general consensus supported by empirical evidence (e.g., $[43,101,112-115])$ that the mixture of functions provides a customer basis for commercial activities, enhances commercial properties and housing markets, encourages investments and renewals, creates closeness between citizens and their workplaces, and improves public transportation infrastructure.

Important to point out is that proximity is typically associated with the compact city model under mixed land use strategy, which is used to achieve not only economic benefits of sustainability, but also environmental and social benefits of sustainability (e.g., [101,112,113]). In reference to the eco-city model, Register (2005) [115], who coined the phrase 'access by proximity,' suggests that closeness to important functions and activities, such as educational and cultural facilities and places for meeting and socializing, is necessary to create ecologically healthy cities characterized by walkable centers, transit villages, discontinuous boulevards, and agricultural land close by. Moreover, proximity, how close jobs, amenities, services, and public spaces are to where people live as generally calculated based on the travel time and distance to their homes, strengthens the self-contained local economy feature of the eco-city that obtains resources locally. In this respect, proximity allows the city to be self-sustaining by having everything that people need within the community, including stores, employers, service providers, energy suppliers, waste handlers, and so on [116].

In fact, the eco-city and compact city models have many overlaps between them in their concepts, ideas, and visions, with some distinctive concepts and key differences for each one of them. According to Roseland 1997) and Harvey (2011) [8,9], a desirable eco-city has a well-designed urban layout that promotes walkability, biking, and the use of public transportation system; ensures decent and affordable housing for all socio-economic and ethnic groups (to be discussed as part of social sustainability); and supports future expansion and progress over time. These features are also at the core of the compact city model as the leading paradigm of sustainable urbanism, in addition to other design strategies, namely density, compactness, and mixed land use (see, e.g., [117-124]). The two models also share mixed land use, as discussed earlier, with the difference being that the mixed-use strategy in the eco-city model is not hand in hand with, or strongly linked to, the high-density strategy as in the compact city model. The goal of the next phase of the redevelopment of the Western Harbor has been adjusted to increase the density significantly [90]. The mixed-use strategy involves four dimensions: the social mix, temporal mix of social and physical issues, physical land use mix, as well as economic mix [125].

In view of the above, Bibri and Krogstie (2019) [3] suggest a complete amalgamation of the eco-city with the compact city as both landscapes and approaches based on several arguments distilled from a detailed review and synthesis of the literature on these two prevailing approaches to sustainable urbanism. Similarly, Farr (2008) [126] discusses the combination of the different elements of ecological urbanism, sustainable urban infrastructure, and new urbanism, coupled with making cities walkable, and then extends this integrated approach to close the loop on resource use and to bring everything into the city. This approach is focused on enhancing the quality of life by affording greater accessibility to activities, services, and facilities within a short distance. Farr's perspective on sustainable urbanism is based on bringing everything closer together, being more efficient, using higher quality goods, having 
everything within walking distance, and closing the loop [127]. However, density and compactness through intensification and how they rely on sustainable transportation are not considered in Farr's approach. In the context of this study, designing an urban district with high population density and intensification is perhaps an aim that is linked to the completion of the two districts.

However, the other key aspects of economic sustainability associated with the two city districts are innovation, research, and public and private sector collaboration. These create an auspicious environment conducive to economic growth and prosperity as manifested in green-tech innovation, production, and export; R\&D activities; entrepreneurial and innovation-based startups; industrial and technological investment; job creation and skill development; government, industry, and academia collaboration; and international cooperation. This is in agreement with the results from other studies (e.g., $[16,48,90])$.

As for social sustainability, the two city districts tie its goals to the creation of an amalgam of social, physical land use, temporal, and economic features. As such, they aim to improve social integration, social cohesion, social capital, and public safety, as well as the quality of life and well-being. More specifically, the two city districts' aims highlight flexible design of housing in terms of types and forms, affordable housing by means of an efficient, careful process, meeting places for social interaction, greater accessibility to services and facilities, ready access to open green and recreational areas, safety and security, housing design enabling residents to remain throughout all stages of life, citizen participation and consultation, and multi-stakeholder cooperation. These are in line with the findings from other studies related to sustainable and ecological urbanism (e.g., [6,16,17,90,101,112,117]). One of the arguments which supports social equity is the possibility to have a better access to services and facilities [128] as well as through the reduction of social segregation [120]. The two city districts are facing some challenges pertaining to the institutionalization of planning practices capable of improving social integration due to the unfordable housing and lack of social mix. In addition, green areas are associated with public health (e.g., [101,112]. Research tends to focus on the health advantages of urban green space $[129,130]$. With respect to multi-stakeholder cooperation, it relates to the different actors that drive the eco-city district project in terms of what role they play in shaping, developing, and managing it. In this respect, for example, while some solutions have to be adapted to the needs of local residents, which indicates that they play a central role when designing the districts, their involvement in the design process is limited as clearly shown in the planning and development documents. This is also found to hold true by Rapoport and Vernay (2011) [17]. All in all, as stated by the Young Foundation (2011), social sustainability is about 'creating sustainable, successful places that promote wellbeing by understanding what people need from the places they live and work. Social sustainability combines design of the physical realm with design of the social world infrastructure to support social and cultural life, social amenities, systems for citizen engagement and space for people and places to evolve.'

In sum, the empirical data show the contours of a goal hierarchy in eco-city district planning and development. Environmental and some economic concerns are at the top of the goal hierarchy supporting eco-city district strategies. In other words, the environmental goals of sustainability dominate over the economic and social goals of sustainability, notwithstanding the claim about the three dimensions of sustainability being equally important at the discursive level. This is visible by the clear structuration of these goals in the planning and development documents and the associated institutionalization of practices supporting these goals. The environmental dimension of sustainability is at the core of the eco-city [17]. Ecological urbanism/the eco-city focuses more on the natural environment and ecosystems and less on economic and social aspects $[18,47]$. This is evident from the environmental and sustainability program for SRS, which is a shortcoming as the social and economic aspects are highly important in the context of sustainable cities, whereas Western Harbor is making strong effort to address social and economic issues within the district by implementing new measures to strengthen the influence of social and economic goals over urban development practices. That is, the basis of social and economic knowledge in planning is expanded through institutionalized mapping 
and registration procedures. While social proposals are usually couched in speculative language in terms of investments, ventures, and employments, the City of Malmo is currently focusing on more socially-oriented projects that have high environmental performances and reduce social inequality and segregation.

The hierarchy of sustainability goals could reflect the challenge of incorporating social and economic issues into a design- and technology-led approach. Perhaps the planners and designers of these districts are simply more knowledgeable about and experienced with how to tackle environmental issues given the long history of environmental work the two cities of Stockholm and Malmö have. The focus in SRS should go beyond the environmental and economic focus to include the social aspects related to the local community. For the two city districts themselves attractiveness does not depend on environment performance and economic prosperity alone. Rather, to attract inhabitants, the two city districts need to develop a broader agenda entailing an amalgam of environmental, economic, and social concerns. And for the two city districts to fully achieve their goal of becoming sustainable urban districts, as they claim, the social and economic aspects of sustainability need to be supported by planning practices and concrete development strategies.

\section{Conclusions}

Eco-city planning and development has long been one of the preferred responses to the challenges of sustainable development. The city districts of SRS and Western Harbor are seen as exemplary practical initiatives in sustainable urbanism, at national, supranational, and international scales. This study has been carried out as a demonstration endeavor of what these two city districts are renowned for in this regard, with the aim of being exposed to both local and general lessons.

The aim of this study was to examine how the eco-city district model, and especially its three sustainability dimensions, is practiced and justified in urban planning and development. Accordingly, it set out to answer the following two questions: what are the key strategies and solutions of the eco-city district model, and in what ways do they mutually complement one another in terms of producing the expected tripartite value of sustainability? To what extent does the eco-city district model support and contribute to the environmental, economic, and social goals of sustainability?

This study shows that the eco-city district models of SRS and Western Harbor involve mainly design and technology, supported with behavioral change, as key strategies and solutions for achieving urban sustainability. Design encompasses greening, passive solar houses, sustainable transportation, mixed land use, and diversity. And technology comprises green technologies, energy efficiency technologies, and waste management systems. Design contributes to the three goals of sustainability, and technology contributes mostly to the environmental and economic goals of sustainability. Behavioral change is associated with sustainable travel, waste separation, and energy consumption. Moreover, the underlying strategies of the eco-city are not mutually exclusive and thus must take place or exist at the same time in order to guarantee the viability and sustain the performance of the eco-city regarding its contribution to the three goals of sustainability. It can be concluded that the eco-city district is a very complex urban development approach that involves several strategies which are supposed to work together in a synergistic way.

The linkages between the dominant strategies of the eco-city district model and the three goals of sustainability can be outlined as follows:

Environmental sustainability: Managing the natural resources base and ecosystems to meet people's needs, and in ways that lower energy consumption, reduce material use, mitigate pollution, and minimize waste.

1. Sustainable energy systems

- Local production of electricity-solar energy;

- $100 \%$ locally renewable energy - sun, wind, and water;

- $\quad$ Bio-fueled CHP system; 
- Passive houses;

- A large-scale smart grid;

- Behavioral change.

2. Sustainable waste management

- Smart waste collecting system;

- Vacuum waste chutes system;

- Food waste disposers;

- Wastewater and sewage treatment system;

- Behavioral change.

3. Sustainable materials

- Recycled and reused materials;

- High performance and resource-effective materials.

4. Sustainable transportation

- Cycling and walking;

- Public transport (metro, buses, tram, etc.);

- Car pools (biogas and electric);

- Mobility management;

- Behavioral change.

5. Greening and ecological diversity

- Multi-functional green structure for ecosystem services;

- Green factor planning tools.

Economic sustainability: Long-term economic growth without negative environmental and social impacts

1. $\quad$ Mixed land use

- Physical land use mix (horizontal/spread of facilities, vertical mix of uses, amenity, public space, etc.);

- Economic mix (business activity, production, consumption, etc.);

- Some aspects of social mix (housing, demography, lifestyles, visitors, etc.).

2. Economic growth and business development

- Green-tech innovation;

- Green-tech production and export;

- R\&D activities;

- Entrepreneurial and innovation-based startups;

- Industrial and technological investment;

- Job creation and skill development;

- Government, industry, and academia collaboration;

- International cooperation. 
Social sustainability: Improving social justice and well-being

1. Social equity

- Social integration;

- Flexible design of housing in terms of types and forms;

- Affordable housing by means of an efficient, careful process;

- Greater accessibility to facilities and services.

2. The quality of life

- Meeting places for social interaction;

- Ready access to recreational and green areas;

- Natural surveillance: safety and security;

- Housing design enabling residents to remain throughout all stages of life.

3. Social cohesion

- Citizen participation and consultation;

- Multi-stakeholder cooperation;

- Well-being of all inhabitants.

In view of the above, the eco-city model as practiced by the two city districts is justified by its ability to contribute to the environmental, economic, and social goals of sustainable development. However, the environmental goals of sustainability dominate over the economic and social goals of sustainability, notwithstanding the claim that the three dimensions of sustainability are equally important at the discursive level. The environmental goals remain at the top of the hierarchy in relation to eco-city development strategies, followed by the economic goals, and then the social goals. Nevertheless, new measures have recently been implemented in Western Harbor that are expected to strengthen their influence over urban development practices. The main issues identified that the two city district are struggling with are socio-economic spatial segregation and unaffordable housing. The SRS program mainly focuses on the environmental aspects, which is a weakness that should be recognized and dealt with as part of ongoing and future urban development endeavors.

More in-depth knowledge on planning and design practices is needed to capture the vision of sustainable urban development, and so too is a deeper understanding of the multi-faceted processes of change to achieve sustainable cities. This entails conceptualizing multiple pathways towards attaining this vision and developing a deeper understanding of the interplay between socio-political and techno-scientific solutions for sustainable urban forms (Williams 2010 and Bibri 2019) [11,13], especially those involving engineering and applied sciences related to big data science and analytics and the underpinning technologies (Bibri 2019) [21,127]. In this regard, the core questions that would potentially broaden our knowledge on how eco-cities can harness their potential through the underlying design strategies and technology innovations and ultimately balance the different dimensions of sustainability in planning and development practices include

- At what stage of the planning process should environmental, economic, and social concerns introduced and even balanced, and what kind of measures are needed to have an effective integration of such concerns early on?

- To what extent can advanced technologies support joined-up planning, a form of integration which enables system-wide sustainability effects to be tracked, understood, and built into the very responses and designs characterizing the operations and functions of the eco-city district, especially in relation to energy, waste, transport, and utilities? 
- What kind of advanced technologies are available and can be implemented to make the planning process dynamic based on constantly updated information on the operations and functions of the eco-city district?

- What is the potential of weaving intelligence functions into the fabric of the eco-city district in terms of its institutions to advance sustainability, optimize efficiency, strengthen resilience, improve equity, and enhance the quality of life for citizenry?

- To what extent can emerging technologies leverage the design strategies and the implementation and operation of other urban technologies associated with the eco-city district in ways that enhance and optimize its processes and practices and evaluate its contribution to sustainability?

It is worth pointing that cities are complex systems par excellence and hence dynamically changing and adaptive; self-organizing social networks embedded in space and enabled by urban infrastructure, activities, and services; and developed by multitudinous collective and individual decisions from top-down and bottom-up [61,131]. In view of that, while computational and scientific approaches are very relevant and important for understanding and dealing with the different aspects of urban complexity through big data analytics and the underpinning technologies, they remain inadequate to solve all urban problems ([132,133]). These are often best solved through political/social solutions, citizen participation, and deliberative democracy, rather than technocratic forms of governance [134,135]. Besides, computational and scientific approaches have been criticized for failing to recognize that cities are complex, intricate, multifaceted, and unpredictable systems, full of contestations and intractabilities that are not easily captured or steered, a view which undoubtedly still holds [11,82,106,110,135-137]. Regardless, focusing only on advanced ICT risks to downplay the complexities associated with realizing smart eco-cities. Still, to successfully implement and manage big data technology as an advanced form of ICT for eco-cities requires a holistic perspective so as to be able to identify and manage gaps and conflicts, as well as to harness synergies between different technological components with respect to functionality, ownership, access, and governance.

We hope that this study has produced the kind of results that will be useful in directing further research by providing the grounding for more in-depth investigation on eco-city planning and development, especially in the developed countries that support sustainable development practices. We would particularly like to encourage qualitative research of the kind that we have attempted, which aims to illuminate the key dimensions underlying the eco-city model and the assumptions behind related initiatives. And hence the claims that this model can make urban living more sustainable. The rationale for this is that as the demand for practical ideas from the ecologically advanced nations about how to achieve the requirements of sustainability through eco-city planning and development increases, those initiatives are likely to attract attention from strategic urban actors around the world. Especially, the two districts aim to provide new knowledge and advanced technology about how to build more sustainable cities. Further research should focus on providing the knowledge that these actors will need to make informed decisions about how to achieve the eco-city objectives in their own context. Moreover, as this study has demonstrated that practices, strategies, and goals already exist across the selected city districts, it would be interesting to pursue, in a future research effort, a wider and more varied comparison (involving cities from other Scandinavian and/or European countries) with a view to revealing more general trends in urban planning and development. In addition, a sequel to this work and thus part of related future research is to integrate the eco-city, the compact city, and the smart data-driven city into a novel model for urban planning and development for the purpose of improving, advancing, and maintaining the contribution of sustainable cities to the goals of sustainable development. This is one among many opportunities that can be explored towards new approaches to sustainable urbanism, predicated on the assumption that there are multiple visions of and pathways to achieving sustainable urbanism. Lastly, we believe that the insights gained from this study can help advance the understanding of how the eco-city phenomenon is evolving and adapting to new global shifts. 
Author Contributions: S.E.B. designed the research, conducted the literature review, collected and analyzed the data, and wrote the manuscript. J.K. performed review and editing. All authors have read and agreed to the published version of the manuscript.

Funding: This research has received no funding.

Conflicts of Interest: The authors declare no conflict of interest.

\section{References}

1. Register, R. Eco-Cities: Building Cities in Balance with Nature; Berkeley Hills Books: Berkeley, CA, USA, 2002.

2. Bibri, S.E.; Krogstie, J. A Scholarly Backcasting Approach to a Novel Model for Smart Sustainable Cities of the Future: Strategic Problem Orientation City. Territ. Archit. 2019, 6, 1-27. [CrossRef]

3. Bibri, S.E.; Krogstie, J. Generating a Vision for Smart Sustainable Cities of the Future: A Scholarly Backcasting Approach. Eur. J. Futures Res. 2019, 7, 1-20. [CrossRef]

4. Council of Europe. The European Urban Charter-Standing Conference of Local and Regional Authorities of Europe. 1993. Available online: http://www.coe.int/T/E/Clrae/ (accessed on 11 November 2012).

5. European Commission. Expert Group on the Urban Environment. In European Sustainable Cities: Report; European Commission: Brussels, Belgium, 1994.

6. Jabareen, Y.R. Sustainable urban forms: Their typologies, models, and concepts. J. Plan. Educ. Res. 2006, 26, 38-52. [CrossRef]

7. Robinson, J.; Tinker, J. Reconciling ecological, economic, and social imperatives. In The Cornerstone of Development: Integrating Environmental, Social, and Economic Policies; Jamie, S., Susan, H., Eds.; IDRC-International Development Research Center and Lewis Publishers: Ottawa, ON, Canada, 1998; pp. 9-43.

8. Harvey, F. Green Vision: The Search for the Ideal Eco-City; Financ Times: London, UK, 2011.

9. Roseland, M. Eco-City Dimensions: Healthy Communities, Healthy Planet; New Society Publisher: Gabriola Island, BC, Canada, 1997.

10. United Nations. Transforming Our World: The 2030 Agenda for Sustainable Development; United Nations: New York, NY, USA, 2015; Available online: https://sustainabledevelopment.un.org/post2015/ transformingourworld (accessed on 22 May 2017).

11. Bibri, S.E. Big Data Science and Analytics for Smart Sustainable Urbanism: Unprecedented Paradigmatic Shifts and Practical Advancements; Springer: Berlin/Heidelberg, Germany, 2019.

12. Bibri, S.E.; Krogstie, J. Smart sustainable cities of the future: An extensive interdisciplinary literature review. Sustain. Cities Soc. 2017, 31, 183-212. [CrossRef]

13. Williams, K. Sustainable cities: Research and practice challenges. Int. J. Urban Sustain. Dev. 2010, 1, 128-132. [CrossRef]

14. Bibri, S.E.; Krogstie, J. ICT of the new wave of computing for sustainable urban forms: Their big data and context-aware augmented typologies and design concepts. Sustain. Cities Soc. 2017, 32, 449-474. [CrossRef]

15. Joss, S.; Cowley, R.; Tomozeiu, D. Towards the ubiquitous eco-city: An analysis of the internationalisation of eco-city policy and practice. J. Urban Res. Pract. 2013, 76, 16-22. [CrossRef]

16. Pandis, I.S.; Brandt, N. The development of a sustainable urban district in Hammarby Sjöstad, Stockholm, Sweden? Environ. Dev. Sustain. 2011, 13, 1043-1064. [CrossRef]

17. Rapoport, E.; Vernay, A.L. Defining the Eco-City: A Discursive Approach. Paper Presented at the Management and Innovation for a Sustainable Built Environment Conference, International Eco-Cities Initiative; Management and Innovation for a Sustainable Built Environment: Amsterdam, The Netherlands, 2011; pp. 1-15.

18. Mostafavi, M.; Doherty, G. (Eds.) Ecological Urbanism; Lars Muller: Baden, Germany, 2010.

19. Bibri, S.E. Smart Sustainable Cities of the Future: The Untapped Potential of Big Data Analytics and Context Aware Computing for Advancing Sustainability; Springer: Berlin/Heidelberg, Germany, 2018.

20. Bibri, S.E. The IoT for smart sustainable cities of the future: An analytical framework for sensor-based big data applications for environmental sustainability. Sustain. Cities Soc. 2018, 38, 230-253. [CrossRef]

21. Bibri, S.E. The anatomy of the data-driven smart sustainable city: Instrumentation, datafication, computerization and related applications. J. Big Data 2019, 6, 59. [CrossRef]

22. Cowley, R. Science fiction and the smart eco-city. In Proceedings of the Society for the History of Technology Annual Meeting 2016, Singapore, 22-26 June 2016. 
23. Höjer, M.; Wangel, S. Smart sustainable cities: Definition and challenges. In ICT Innovations for Sustainability; Hilty, L., Aebischer, B., Eds.; Springer: Berlin/Heidelberg, Germany, 2015; pp. 333-349.

24. Kramers, A.; Höjer, M.; Lövehagen, N.; Wangel, J. Smart sustainable cities: Exploring ICT solutions for reduced energy use in cities. Environ. Model. Softw. 2014, 56, 52-62. [CrossRef]

25. Späth, P. (Ed.) Smart-Eco Cities in Germany: Trends and City Profiles; University of Exeter (SMART-ECO Project): Exeter, UK, 2017.

26. Yigitcanlar, T.; Lee, S.H. Korean ubiquitous-eco-city: A smart-sustainable urban form or a branding hoax? J. Technol. For Soc. Chang. 2013, 89, 100-114. [CrossRef]

27. Moore, S.A. Alternative Routes to the Sustainable City: Austin, Curitiba, and Frankfurt; Lexington Books: Lanham, MD, USA, 2007.

28. Wheeler, S.M.; Beatley, T. (Eds.) The Sustainable Urban Development Reader; Routledge: London, UK; New York, NY, USA, 2010.

29. Van der Ryn, S.; Calthorpe, P. Sustainable Communities: A New Design Synthesis for Cities, Suburbs, and Towns; Sierra Club Books: San Francisco, CA, USA, 1991.

30. Joss, S. Eco-cities: The mainstreaming of urban sustainability; key characteristics and driving factors. Int. J. Sustain. Dev. Plan. 2011, 6, 268-285. [CrossRef]

31. Roelofs, J. Building and designing with nature: Urban design. In Sustainable Cities; David, S., Ed.; Earthscan: London, UK, 1999; pp. 234-250.

32. Engwicht, D. Towards an Eco-City: Calming the Traffic; Envirobook: Sydney, Australia, 1992.

33. OECD. Ecological Cities Project. 1995. Available online: http://www.oecd.org (accessed on 15 February 2006).

34. Girardet, H. Creating Sustainable Cities. Schumacher Briefing no. 2; Green Books: Devon, UK, 1999.

35. Nijkamp, P.; Adriaan, P. Sustainable Cities in Europe; Earthscan: London, UK, 1994.

36. Gibbs, D.C.; Longhurst, J.; Braithwaite, C. Struggling with sustainability: Weak and strong interpretations of sustainable development within local authority policy. Environ. Plan. A 1998, 30, 1351-1365. [CrossRef]

37. Rudin, D.; Nicholas, F. Building the 21st Century Home: The Sustainable Urban Neighborhood; Architectural Press: Oxford, UK, 1999.

38. Girardet, H. The Gaia Atlas of Cities: New Directions for Sustainable Urban Living; Gaia Books: London, UK, 1992.

39. Todd, J.; Nancy, T. From Eco-Cities to Living Machines: Principles of Ecological Design; North Atlantic Books: Berkeley, CA, USA, 1994.

40. Zhou, N.; He, G.; Williams, C. China's Development of Low-Carbon Eco-Cities and Associated Indicator Systems. Report LBNL-5873E, China Energy Group Energy Analysis \& Environmental Impacts Department, Ernest Orlando Lawrence Berkley National Laboratory. July 2012. Available online: http://china.lbl.gov/ sites/all/fles/china_eco--cities_indicator_systems.pdf (accessed on 12 November 2019).

41. Ranhagen, U.; Groth, K. The Symbio City Approach-A Conceptual Framework for Sustainable Urban Development; SKL International: Stockholm, Sweden, 2012.

42. McGregor, A.; Roberts, C.; Cousins, F. Two Degrees: The Built Environment and Our Changing Climate; Routledge: New York, NY, USA, 2013.

43. Suzuki, H.; Dastur, A.; Moffatt, S.; Yabuki, N.; Maruyama, H. Eco2 Cities Ecological Cities as Economic Cities; The World Bank: Washington, DC, USA, 2010.

44. Graedel, T. Industrial ecology and the ecocity. Bridge 1999, 29, 4-9.

45. Kärrholm, M. The scaling of sustainable urban form: Some scale-Related problems in the context of a Swedish urban landscape. Eur. Plan. Stud. 2011, 19, 97-112. [CrossRef]

46. Cugurullo, F. Exposing smart cities and eco-cities: Frankenstein urbanism and the sustainability challenges of the experimental city. Environ. Plan. A Econ. Space 2016, 50, 73-92. [CrossRef]

47. Holmstedt, L.; Brandt, N.; Robert, K.H. Can Stockholm Royal Seaport be part of the puzzle towards global sustainability? From local to global sustainability using the same set of criteria. J. Clean. Prod. 2017, 140, 72-80. [CrossRef]

48. Kramers, A.; Wangel, J.; Höjer, M. Governing the smart sustainable city: The case of the Stockholm Royal Seaport. In Proceedings of ICT for Sustainability; Atlantis Press: Amsterdam, The Netherlands, 2016; Volume 46, pp. 99-108.

49. Creswell, J.W.; Hanson, W.E.; Clark Plano, V.L.; Morales, A. Qualitative research designs: Selection and implementation. Couns. Psychol. 2007, 35, 236-264. [CrossRef] 
50. Yin, R.K. Case Study Research: Design and Methods, 4th ed.; Sage: London, UK, 2009.

51. Yin, R.K. Case Study Research and Applications, 6th ed.; Design and Methods; SAGE Publications, Inc.: London, UK, 2017.

52. Flyvbjerg, B. Case study. In The Sage Handbook of Qualitative Research, 4th ed.; Denzin, N.K., Lincoln, Y.S., Eds.; Sage: Thousand Oaks, CA, USA, 2011; pp. 301-316.

53. Merriam, S.B. Qualitative Research: A Guide to Design and Implementation, 2nd ed.; Jossey-Bass: San Francisco, CA, USA, 2009.

54. Stake, R.E. Multiple Case Study Analysis; Guilford: New York, NY, USA, 2006.

55. Yin, R.K. Case Study Research: Design and Methods; Sage: Los Angeles, CA, USA, 2014.

56. Simons, H. Case Study Research in Practice; Sage: Los Angeles, CA, USA, 2009.

57. Stewart, A. Case study. In Qualitative Methodology: A Practical Guide; Jane, M., Melanie, B., Eds.; Sage: Thousand Oaks, CA, USA, 2014; pp. 145-159.

58. Dryzek, J.S. The Politics of the Earth. Environmental Discourses, 2nd ed.; Oxford University Press: Oxford, UK, 2005.

59. Mol, A.P.J. Ecological Modernization and the Global Economy. Glob. Environ. Politics 2002, 2, 92-115. [CrossRef]

60. Baldersheim, H.; Ståhlberg, K. From Guided Democracy to Multilevel Governance: Trends in Central—Local relations in the Nordic countries. Local Gov. Stud. 2002, 28, 74-90. [CrossRef]

61. Bibri, S.E. Advances in the Leading Paradigms of Urbanism and Their Amalgamation: Compact Cities, Eco-cities, and Data-Driven Smart Cities; Springer Nature Switzerland AG: Cham, Switzerland, 2020.

62. European Green Capital. The Expert Panel's Evaluation Work Final Recom-Mendations for the European Green Capital Award of 2010 and 2011; European Commission: Brussels, Belgium, 2009.

63. Lindström, B.; Eriksson, B. Quality of life among children in the Nordic countries. Q. Life Res. 1993, 2, $23-32$. [CrossRef] [PubMed]

64. Stockholm City 2009b, Stockholm City Plan. Available online: https://vaxer.stockholm/globalassets/tema/ oversiktplan-ny_light/english_stockholm_city_plan.pdf (accessed on 10 October 2019).

65. Stockholm City 2009c, Stockholm Royal Seaport: Vision 2030. Available online: https://international. stockholm.se/globalassets/ovriga-bilder-och-filer/visionsrs2030_medium.pdf (accessed on 15 October 2019).

66. Stockholm City 2019, Royal Seaport Stockholm. Available online: http://www.stockholmroyalseaport.com (accessed on 13 November 2019).

67. Stockholm City 2009a, Stockholm City Plan. Available online: https://www.google.com/search?client=safari\& channel=mac_bm\&sxsrf=ACYBGNRBW8_dDG-xq9KckAdoe504Heffxg\%3A1572425899931\&source= hp\&ei=q1C5XaeRNY3RrgTI57aYCg\&q=Stockholm+Master+plan+\&btnK=Google+Search (accessed on 22 September 2019).

68. SCB. 2018 Folkmängd och Landareal i Tätorter, Per Tätort. Vart Femte år 1960-2018. Available online: http://www.statistikdatabasen.scb.se/pxweb/sv/ssd/START__MI_MI0810__MI0810A/ LandarealTatort/?rxid=546e87f6-5dc3-4535-994e-b301c2515080 (accessed on 25 October 2019).

69. Malmö City. Western Harbor, Current Urban Planning. 2015. Available online: https: //malmo.se/download/18.76b7688614bb5ccea09157af/1491304414891/Current+urban+development+ in+Western+Harbour+\%282015\%29.pdf (accessed on 21 May 2019).

70. Stockholm City Council. Övergripande Program för Miljö Och Hållbar Stadsutveckling i Norra Djurgårdsstaden; Stockholm City Council: Stockholm, Sweden, 2010.

71. Fortum. Fortum Värme Och Miljö Stockholm 2013; Fortum: Stockholm, Sweden, 2013.

72. Fortum, 2012. Fortum to Invest in a New Biofuelled Combined Heat and Power Plant in Stockholm. Sweden. Available online: http://www.fortum.com/en/mediaroom/Pages/fortum-to-invest-in-a-newbiofuelled-combined-heat-and-power-plant-in-stockholm-sweden.aspx (accessed on 4 March 2015).

73. Stockholm City 2017, Stockholm Royal Seaport: Sustainability Report. Available online: https://vaxer.stockholm/globalassets/omraden/-stadsutvecklingsomraden/ostermalm-norradjurgardsstaden/royal-seaport/media/sustainability_report_2017_uppslag_eng_juni_2018.pdf (accessed on 22 November 2019).

74. The Nordics, Smart City Solutions. 2017. Available online: http://www.nordicpavilion.org/stockholm-royalseaport-2018/ (accessed on 19 October 2019). 
75. Malmö City 2014, Comprehensive Plan for Malmö. Available online: https://malmo.se/Nice-to-knowabout-Malmo/Sustainable-Malmo-/Sustainable-Urban-Development/Sustainable-Urban-Planning.html (accessed on 14 April 2019).

76. Malmö City 2006, Västra Hamnen The Bo01-Area: A City for People and the Environment. Available online: https://malmo.se/download/18.7101b483110ca54a562800010420/ (accessed on 18 October 2012).

77. Akande, A.; Gomes, P.; Cabral, P. The Lisbon Ranking for Smart Sustainable Cities in Europe. Sustain. Cities Soc. 2019, 44, 475-487. [CrossRef]

78. Johannesson, C. City of S.: Interview Claes Johannesson, smart city Stockholm, Project leader. 2018.

79. Shahrokni, H.; Lazarevic, D.; Brandt, N. Smart Urban Metabolism: Towards a Real-Time Understanding of the Energy and Material Flows of a City and Its Citizens. J. Urban Technol. 2015, 22, 65-86. [CrossRef]

80. Shahrokni, H.; Årman, L.; Lazarevic, D.; Nilsson, A.; Brandt, N. Implementing smart urban metabolism in the Stockholm Royal Seaport: Smart city SRS. J. Ind. Ecol. 2015, 19, 917-929. [CrossRef]

81. Bibri, S.E.; Krogstie, J. The big data deluge for transforming the knowledge of smart sustainable cities: A data mining framework for urban analytics. In Proceedings of the 3rd Annual International Conference on Smart City Applications, Tetouan, Morocco, 10-11 October 2018.

82. Kitchin, R. The real-time city? Big data and smart urbanism. Geo J. 2014, 79, 1-14. [CrossRef]

83. Townsend, A. Smart Cities—Big Data, Civic Hackers and the Quest for a New Utopia; Norton \& Company: New York, NY, USA, 2013.

84. Harris, D.J. A quantitative approach to the assessment of the environmental impact of building materials. Build. Environ. 1999, 34, 751-758. [CrossRef]

85. Stockholms Länslandsting, 2015. Spårvagn City. Available online: http://www.sll.se/verksamhet/ kollektivtrafik/aktuella-projekt/sparvag-city/ (accessed on 12 February 2015).

86. Klockner, C.A.; Matthies, E. How habits interfere with norm-directed behaviour: A normative decision-making model for travel mode choice. J. Environ. Psychol. 2004, 24, 319-327. [CrossRef]

87. Pozdniakova, A.M. Smart city strategies "London-Stockholm-Vienna-Kyiv": In search of common ground and best practices. Acta Innov. 2018, 27, 31-45. [CrossRef]

88. Foletta, N.; Field, S. Europe's Vibrant New Low Car(bon) Communities; Institute for Transportation \& Development Policy: New York, NY, USA, 2011; Available online: http://www.itdp.org/documents/092211_ ITDP_NED_Desktop_Print.pdf (accessed on 29 March 2013).

89. Reepalu, I. Malmö-From Industrial Waste Land to Sustainable City. Climate Action. 16 September 2013. Available online: http://www.climateactionprogramme.org/climate-leader-papers/ilmar_reepalu_mayor_ city_of_malmoe_sweden/ (accessed on 13 March 2016).

90. Austin, G. Case study and sustainability assessment of Bo01, Malmo, Sweden. J. Green Build. Summer 2013, 8, 34-50. [CrossRef]

91. Bradley, K.; Gunnarsson-Östling, U.; Isaksson, I. Exploring Environmental Justice in Sweden-How to improve planning for environmental sustainability and social equity in an 'eco-friendly' context. Projections MIT J. Plan. 2008, 8, 68-81.

92. Talen, E.; Ellis, C. Beyond relativism: Reclaiming the search for good city form. J. Plan. Educ. Res. 2002, 22, 36-49. [CrossRef]

93. Gordon, H. Sustainable design goes main stream. In Sustainable Architecture: White Papers; Brown, D., Fox, M., Pelletier, M.R., Eds.; Earthpledge: New York, NY, USA, 2005; pp. 34-38.

94. Owens, S. Energy, environmental sustainability and land-Use planning. In Sustainable Development and Urban Form; Breheny, M., Ed.; Pion: London, UK, 1992; pp. 79-105.

95. Thomas, R. Building design. In Sustainable Urban Design: An Environmental Approach; Randall, T., Fordham, M., Eds.; Spon Press: London, UK, 2003; pp. 46-88.

96. Yeang, K. The Skyscraper Bioclimatically Considered; Academy: London, UK, 1997.

97. Marcotullio, P. Urban water-related environmental transitions in Southeast Asia. Sustain. Sci. 2007, 2, 27-54. [CrossRef]

98. Jenks, M.; Burton, E.; Williams, K. A sustainable future through the compact city? Urban intensification in the United Kingdom. Environ. Des. 1996, 1, 5-20.

99. Jenks, M.; Burton, E.; Williams, K. (Eds.) The Compact City: A Sustainable Urban Form? E \& FN Spon Press: London, UK, 1996. 
100. Kenworthy, J.R. The eco-city: Ten key transport and planning dimensions for sustainable city development. Environ. Urban. 2006, 18, 67-85. [CrossRef]

101. Bibri, S.E.; Krogstie, J.; Karrholm, M.J. Compact City Planning and Development: The Cases of Gothenburg and Helsingborg, Sweden. Sustain. Cities Soc. 2020, in press.

102. Swanwick, C.; Dunnett, N.; Woolley, H. Nature, role and value of green space in towns and cities: An overview. Built Environ. 2003, 29, 94-106. [CrossRef]

103. Länsstyrelsen Stockholm. Nationalstadsparken. 2015. Available online: http://www.lansstyrelsen. se/stockholm/Sv/samhallsplanering-och-kulturmiljo/planfragor/riksintressen/nationalstadspark/Pages/ default.aspx (accessed on 11 October 2019).

104. Van Bueren, E.; van Bohemen, H.; Itard, L.; Visscher, H. Sustainable Urban Environments: An Ecosystem Approach; Springer, International Publishing: Berlin, Germany, 2011.

105. Angelidou, M.; Artemis, P.; Nicos, K.; Christina, K.; Tsarchopoulos, P.; Anastasia, P. Enhancing sustainable urban development through smart city applications. J. Sci. Technol. Policy. Manag. 2018, 9, 146-169. [CrossRef]

106. Batty, M.; Axhausen, K.W.; Giannotti, F.; Pozdnoukhov, A.; Bazzani, A.; Wachowicz, M.; Ouzounis, G.; Portugali, Y. Smart cities of the future. Eur. Phys. J. 2012, 214, 481-518. [CrossRef]

107. Bibri, S.E. On the sustainability of smart and smarter cities in the era of big data: An interdisciplinary and transdisciplinary literature review. J. Big Data 2019, 6, 25. [CrossRef]

108. Gebresselassiea, M.; Sanchez, T.M. Smart' tools for socially sustainable transport. J. Urban Sci. 2018,2 , 45. [CrossRef]

109. Al Nuaimi, E.; Al Neyadi, H.; Nader, M.; Al-Jaroodi, J. Applications of big data to smart cities. J. Internet Serv. Appl. 2015, 6, 1-15. [CrossRef]

110. Bettencourt, L.M.A. The Uses of Big Data in Cities; Santa Fe Institute: Santa Fe, NM, USA, 2014.

111. Bibri, S.E. A foundational framework for smart sustainable city development: Theoretical, disciplinary, and discursive dimensions and their synergies. Sustain. Cities Soc. 2018, 38, 758-794. [CrossRef]

112. Hofstad, H. Compact city development: High ideals and emerging practices. Eur. J. Spat. Dev. 2012, 1-23.

113. Jones, C.; Jenks, M.; Bramley, G. Compl ementarities and Contradictions. In Dimensions of the Sustainable City; Jenks, M., Jones, C., Eds.; SpringerLink: London, UK, 2010; Volume 2, pp. 239-256.

114. OECD. Compact City Policies: A Comparative Assessment, OECD. In OECD Green Growth Studies; OECD Publishing: Paris, France, 2012; pp. 123-158. [CrossRef]

115. Register, R. Ecocities: Rebuilding Cities in Balance with Nature; New Society Publishers: Gabriola Island, BC, Canada, 2006.

116. Li, L.W.; Yu, Y.H. Planning Low Carbon Communities: Why Is a Self-Sustaining Energy Management System Indispensable? Energy Sources Part B Econ. Plan. Policy 2016, 11, 371-376. [CrossRef]

117. Arbury, J. From Urban Sprawl to Compact City-An Analysis of Urban Growth Management in Auckland. 2005, p. 175. Available online: http://portal.jarbury.net/thesis.pdf (accessed on 12 September 2015).

118. Breheny, M. (Ed.) Sustainable Development and Urban Form; Pion: London, UK, 1992.

119. Breheny, M.J. Urban compaction: Feasible and acceptable? Cities 1997, 14, 209-217. [CrossRef]

120. Burton, E. The Compact City and Social Justice. In Housing, Environment and Sustainability, Housing Studies Association Spring Conference; University of York: York, UK, 2001.

121. Burton, E. Measuring urban compactness in UK towns and cities. Environ. Plan. B Plan. Des. 2002, 29, 219-250. [CrossRef]

122. Dempsey, N. Revisiting the Compact City? Built Environ. 2010, 36, 5-8. [CrossRef]

123. Jenks, M.; Dempsey, N. Future Forms and Design for Sustainable Cities; Elsevier: Oxford, UK, 2005.

124. Jenks, M.; Jones, C. (Eds.) Dimensions of the Sustainable City; SpringerLink: London, UK, 2010; Volume 2.

125. Evans, G.; Foord, J. The Generation of Diversity: Mixed Use and Urban Sustainability, Urban Sustainability through Environmental Design; Kevin, T., Sergio, P., Ombretta, R., Eds.; Taylor \& Francis Group: Abingdon, UK, 2007.

126. Farr, D. Sustainable Urbanism; John Wiley \& Sons, Inc.: New York, NY, USA, 2008.

127. Sharifi, A. From Garden City to Eco-urbanism: The quest for sustainable neighborhood development. Sustain. Cities Soc. 2016, 20, 1-16. [CrossRef]

128. Burton, E. The compact city: Just or just compact? A preliminary analysis. Urban Stud. 2000, 37, $1969-2006$. [CrossRef] 
129. De Vries, S.; Verheij, R.A.; Groenewegen, P.P.; Spreeuwenberg, P. Natural environments-healthy environments? An exploratory analysis of the relationshi p between greenspace and health. Environ. Plan. A 2013, 35, 1717-1731. [CrossRef]

130. Maas, J.; Verheij, R.A.; Groenewegen, P.P.; de Vries, S.; Spreeuwenburg, P. Green space, urbanity, and health: How strong is the relation? J. Epidemiol. Community Health 2006, 60, 587-592. [CrossRef] [PubMed]

131. Bibri, S.E. Advances in Smart Sustainable Urbanism: Data-Driven and Data-Intensive Scientific Approaches to Wicked Problems. In Proceedings of the 4th Annual International Conference on Smart City Applications, Casablanca, Morocco, 2-4 October 2019; ACM: New York, NY, USA, 2019.

132. Bibri, S.E. The Sciences Underlying Smart Sustainable Urbanism: Unprecedented Paradigmatic and Scholarly Shifts in Light of Big Data Science and Analytics. Smart Cities 2019, 2, 13. [CrossRef]

133. Bibri, S.E. Data-Driven Smart Sustainable Urbanism: The Intertwined Societal Factors Underlying its Materialization, Success. Expans. Evol. Geoj. 2019. [CrossRef]

134. Greenfield, A. Against the Smart City; Do Publications: New York, NY, USA, 2013.

135. Kitchin, R.; Lauriault, T.P.; McArdle, G. Knowing and governing cities through urban indicators, city benchmarking and real-time dashboards. Reg. Stud. Reg. Sci. 2015, 2, 1-28. [CrossRef]

136. Bibri, S.E.; Krogstie, J. On the social shaping dimensions of smart sustainable cities: A study in science, technology, and society. Sustain. Cities Soc. 2016, 29, 219-246. [CrossRef]

137. Kitchin, R. The ethics of smart cities and urban science. Philos. Trans. R. Soc. A 2016, 374, 1-15. [CrossRef]

(C) 2020 by the authors. Licensee MDPI, Basel, Switzerland. This article is an open access article distributed under the terms and conditions of the Creative Commons Attribution (CC BY) license (http://creativecommons.org/licenses/by/4.0/). 